\title{
Variability in regional background aerosols within the Mediterranean
}

\author{
X. Querol ${ }^{1}$, A. Alastuey ${ }^{1}$, J. Pey ${ }^{1}$, M. Cusack ${ }^{1}$, N. Pérez ${ }^{1}$, N. Mihalopoulos ${ }^{2}$, C. Theodosi ${ }^{2}$, E. Gerasopoulos ${ }^{3}$, \\ N. Kubilay ${ }^{4}$, and M. Koçak ${ }^{4}$ \\ ${ }^{1}$ Institute of Environmental Assessment and Water Research (IDÆA), Dept. of Geosciences CSIC, LLuis Solé i Sabarís S/N, \\ 08028 Barcelona, Spain \\ ${ }^{2}$ Environmental Chemical Processes Laboratory, Dept. of Chemistry, University of Crete, P.O. Box 1470, 71409 \\ Heraklion, Greece \\ ${ }^{3}$ Institute for Environmental Research and Sustainable Development, National Observatory of Athens, Metaxa \& V. Pavlou, \\ 15236, Athens, Greece \\ ${ }^{4}$ Institute of Marine Sciences, Middle East Technical University, P.O. Box 38, 33731, Erdemli-Mersin, Turkey
}

Received: 5 March 2009 - Published in Atmos. Chem. Phys. Discuss.: 23 April 2009

Revised: 19 June 2009 - Accepted: 23 June 2009 - Published: 16 July 2009

\begin{abstract}
The main objective of this study is the identification of major factors controlling levels and chemical composition of aerosols in the regional background (RB) along the Mediterranean Basin (MB). To this end, data on PM levels and speciation from Montseny (MSY, NE Spain), Finokalia (FKL, Southern Greece) and Erdemli (ERL, Southern Turkey) for the period 2001 to 2008 are evaluated. Important differences on PM levels and composition are evident when comparing the Western and Eastern MBs. The results manifest $\mathrm{W}-\mathrm{E}$ and $\mathrm{N}-\mathrm{S} \mathrm{PM}_{10}$ and $\mathrm{PM}_{2.5}$ gradients along the $\mathrm{MB}$, attributed to the higher frequency and intensity of African dust outbreaks in the EMB, while for $\mathrm{PM}_{1}$ very similar levels are encountered.

PM in the EMB is characterized by higher levels of crustal material and sulphate as compared to WMB (and central European sites), however, RB nitrate and $\mathrm{OC}+\mathrm{EC}$ levels are relatively constant across the Mediterranean and lower than other European sites. Marked seasonal trends are evidenced for PM levels, nitrate (WMB), ammonium and sulphate. Also relatively higher levels of $\mathrm{V}$ and $\mathrm{Ni}$ (WMB) are measured in the Mediterranean basin, probably as a consequence of high emissions from fuel-oil combustion (power generation, industrial and shipping emissions).

Enhanced sulphate levels in EMB compared to WMB were measured. The high levels of sulphate in the EMB may deplete the available gas-phase $\mathrm{NH}_{3}$ so that little ammonium nitrate can form due to the low $\mathrm{NH}_{3}$ levels.
\end{abstract}

Correspondence to: X. Querol (xavier.querol@idaea.csic.es)
This study illustrates the existence of three very important features within the Mediterranean that need to be accounted for when modeling climate effects of aerosols in the area, namely: a) the increasing gradient of dust from WMB to EMB; b) the change of hygroscopic behavior of mineral aerosols (dust) via nitration and sulfation; and c) the abundance of highly hygroscopic aerosols during high insolation (low cloud formation) periods.

\section{Introduction}

Tropospheric aerosols have been the object of intensive research mainly because of their impact on health (Pope and Dockery, 2006), the Earth's climate (IPCC, 2007), visibility, ecosystems and building materials. Air quality degradation by particulate matter (PM) over polluted areas is often characterized by high levels of regional background (RB) aerosols on which intense episodes of either natural or anthropogenic origins are superimposed. Such episodes are associated with synoptic and mesoscale meteorological conditions that favour formation and accumulation of aerosol pollutants at regional or even continental scales. The exclusive measurement of aerosols in highly polluted areas and at a local scale may prevent adequate interpretation of the origin of pollution episodes. On the contrary, measurements performed at RB sites, seem to optimize accurate documentation on both aerosol long-term trends and relevant synoptic features. The importance of this type of measurement site is highlighted by the creation of the EU-wide EUSAAR network (European Supersites for Atmospheric

Published by Copernicus Publications on behalf of the European Geosciences Union. 
Aerosol Research, EU 6th framework, EUSAAR RII3-CT2006-026140), which seeks to integrate the measurements of atmospheric aerosol properties at 21 high quality European ground-based stations.

Reports from countries around the Mediterranean Basin and Eastern Europe show especially high levels of atmospheric PM compared to Northern and some central European regions. Both anthropogenic (transport sector, industrial processes, power generation, biomass burning, among others) and natural (African dust, resuspension, sea spray, forest fires, primary biological particles, biogenic secondary organic compounds) emissions, as well as orographic and climatic factors contribute to those enhanced PM levels.

A number of individual studies are available on the variability of RB-PM levels for Western (e.g. Querol et al., 1998; Rodriguez et al., 2002, 2004; Pérez et al., 2008) and Eastern Mediterranean (e.g. Koçak et al., 2007a; Gerasopoulos et al., 2007), and to a lesser extent on PM speciation (e.g. Rodriguez et al., 2003; Querol et al., 2004, 2008; Marenco et al., 2006; Viana et al., 2008; Dongarrà et al., 2007; Saliba et al., 2007; Koçak et al., 2007b; Koulouri et al., 2008; Glavas et al., 2008). However, there is a lack of comparative studies on the variability of PM levels and composition along the Mediterranean Basin, necessary for understanding the special features that differentiate aerosol processes and aerosolclimate interactions between WMB and EMB, for instance.

This study aims to summarise the results on levels and chemical composition of RB-PM along the Mediterranean Basin, with special attention giving to the comparison between $\mathrm{WMB}$ and EMB, in order to identify and discriminate the major controlling factors. Special focus is given to the identification and interpretation of daily and seasonal patterns and the influence of certain atmospheric transport on PM composition and levels, with emphasis on African dust outbreaks and regional pollution episodes. Additionally, the Mediterranean situation will be put into context with the corresponding situation over Central and Northern Europe, by comparison with similar studies performed in other regions in Europe. For this purpose, PM speciation data from the Montseny (MSY, NE Spain) and Finokalia (FKL, Crete Island, Southern Greece) sites, both EUSAAR sites and Erdemli (ERL, Southern Turkey), obtained during the period 2001-2007, are evaluated in this paper.

\section{Atmospheric dynamics and sources of PM along the Mediterranean}

The WMB presents peculiar and complex atmospheric dynamics affected by mesoscale and local meteorological processes but also regional factors, such as: 1) the considerable influence of the Azores high-pressure system in the meteorology of the Iberian Peninsula (IP); 2) the coastal ranges surrounding the Mediterranean coast (Fig. 1); 3) the influence of the Iberian and Saharan thermal lows causing weak pressure gradients over the Mediterranean; 4) the intense breeze action along the Mediterranean coast favoured by the prevailing low advective conditions; 5) the scarce summer precipitation; and 6) the intense seasonal contrast concerning temperature, humidity and rainfall (Millán et al., 1997; Soriano et al., 2001; Gangoiti et al., 2001; Rodríguez et al., 2002, 2003; Jorba et al., 2004; Pérez et al., 2004).

Similarly, the EMB meteorology is controlled by the following main factors: 1) during spring and early summer the development of Saharan depressions to the south of the Atlas Mountains take place (Moulin et al., 1998). These cyclones move eastwards, across the Mediterranean between Libya and Egypt and are responsible for the transport of large amounts of desert dust over the EMB; 2) during summer the EMB is influenced by the Azores anticyclone extended to the east and the cyclonic branch of the large South Asian thermal low. Additionally, a strong influence of the Indian Monsoon on the dry Mediterranean climate (Rodwell and Hoskins, 2001), combined with the complex orographic terrain of regions such as Greece, result in persistent northerly winds, called "Etesians". As a result, the EMB is influenced by advection from Europe in the lower troposphere, favouring the transport of particles from urban areas of central and Eastern Europe as well as from areas with intense biomass burning (Balis et al., 2003; Sciare et al., 2008).

The overall area is characterized by abrupt topography, influencing the synoptic winds (Fig. 1). Although the Mediterranean Basin contains extensive regions of semi-arid soils, most of the ranges are mainly covered by typical Mediterranean and coniferous forests. The main densely populated areas and urban conglomerations (e.g. Barcelona, Valencia, Marseille, Rome, Athens, Istanbul and Cairo), industrial settlements, dense road and ships traffic paths, all constituting large anthropogenic emission sources, are located along the coastal areas.

All the above factors give rise to a scenario of a particularly complex aerosol phenomenology, with large anthropogenic and natural emissions, significant secondary aerosol formation and transformation, and intensive interaction between aerosols and gaseous pollutants. It is also noticeable that the intensive meteorological contrast along the year (temperature, humidity and rainfall) causes marked seasonal patterns for specific PM components.

\section{Methodology}

\subsection{Monitoring sites}

The MSY $\left(41^{\circ} 46^{\prime} \mathrm{N} ; 02^{\circ} 21^{\prime} \mathrm{E}, 720 \mathrm{~m}\right.$ a.s.1.), FKL $\left(35^{\circ} 20^{\prime} \mathrm{N}\right.$; $25^{\circ} 40^{\prime} \mathrm{E}, 230 \mathrm{~m}$ a.s.l. $)$, and ERL $\left(36^{\circ} 36^{\prime} \mathrm{N} ; 34^{\circ} 18^{\prime} \mathrm{E}\right.$, $22 \mathrm{~m}$ a.s.1.) monitoring stations are selected due to their representative locations as typical for western and eastern Mediterranean RB sites and also because they have a longterm data series of PM concentrations and chemical composition. 


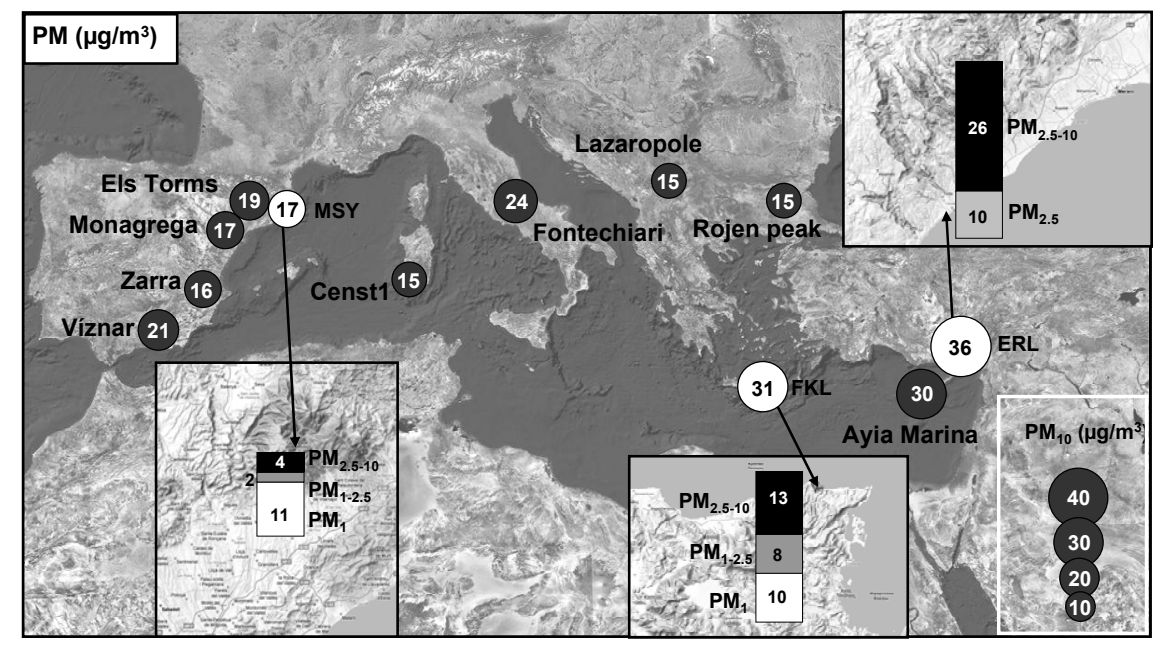

Fig. 1. Location of the monitoring sites over the Mediterranean Basin. Mean annual $\mathrm{PM}_{1}, \mathrm{PM}_{1-2.5}$ and $\mathrm{PM}_{2.5-10} \mathrm{levels}\left(\mu \mathrm{g} / \mathrm{m}^{3}\right)$ at $\mathrm{MSY}$, FKL and ERL. Mean annual $\mathrm{PM}_{10}$ levels at other regional background monitoring sites across the Mediterranean Basin. White circles show data from this study, shadowed circles show data from Airbase.

MSY is situated at the Montseny Natural Park located $40 \mathrm{~km}$ to the NNE of Barcelona metropolitan area (around 3.5 million inhabitants), $25 \mathrm{~km}$ from the Mediterranean coast. The station is located at La Castanya, a perpendicular valley to the coast inside the Catalan Pre-Coastal Ranges (Fig. 1). Even though the station is relatively far from urban and industrial agglomerations, it should be noted that the adjacent regions are highly populated and industrialized, and anthropogenic emissions may affect this site under specific meteorological scenarios. Atmospheric dynamics and aerosol variability at MSY are described in detail by Pérez et al. (2008).

FKL is situated in the northern coast of Crete Island, $70 \mathrm{~km}$ east of Heraklion, which is the nearest largest city of the island with 0.15 million inhabitants. The station is located at the top of a hill and faces the sea to the north within a sector of $270^{\circ}$ to $90^{\circ}$ (Mihalopoulos et al., 1997). According to the criteria proposed by the European Environment Agency (Larssen et al., 1999), FKL is characterized as a "natural background" station, with characteristics of a remote coastal site, and only under specific meteorological circumstances can be affected by anthropogenic pollution from short (Heraklion) and medium (Athens) range transport. A recent description of the prevailing winds has been reported by Gerasopoulos et al. (2005).

ERL is located on the coastline of South Turkey in the EM ( $36^{\circ} 33^{\prime} 54^{\prime \prime} \mathrm{N}$ and $\left.34^{\circ} 15^{\prime} 18^{\prime \prime} \mathrm{E}\right)$. The sampling site is rural and not under direct influence from industrial activities. The nearest city (Mersin) is located $45 \mathrm{~km}$ to the east of the sampling site and has a population of 0.74 million inhabitants (Kubilay et al., 2000; Koçak et al., 2004, 2007b).

\subsection{Sampling methods and measurements}

\subsubsection{MSY station}

At MSY, $\mathrm{PM}_{10}, \mathrm{PM}_{2.5}$ and $\mathrm{PM}_{1}$ are continuously measured since March 2002 using real time optical counters (GRIMM 1107) which are corrected with gravimetric measurements. 24-h $\mathrm{PM}_{10}$ and $\mathrm{PM}_{2.5}$ samples are collected on $150 \mathrm{~mm}$ quartz micro-fibre filters (Schleicher and Schuell, QF20) using high volume samplers $\left(30 \mathrm{~m}^{3} / \mathrm{h}\right)$ and DIGITEL cut-off inlets. Originally, TSP and $\mathrm{PM}_{2.5}$ were sampled weekly (a mean of 2 samples of TSP and 1 sample of $\mathrm{PM}_{2.5}$ per week), but in 2004 TSP sampling was replaced by $\mathrm{PM}_{10}$.

Overall, 188 (March 2002-January 2004), 442 (January 2004-December 2007) and 255 (March 2002-December 2007) samples of TSP, $\mathrm{PM}_{10}$ and $\mathrm{PM}_{2.5}$, respectively, were analyzed. PM mass concentrations were determined by standard gravimetric procedures. Thereafter, $1 / 2$ of each filter was acid digested ( $\left.\mathrm{HF}: \mathrm{HNO}_{3}: \mathrm{HClO}_{4}\right)$ for the determination of major and trace elements by ICP-AES and ICP-MS. Another $1 / 4$ of each filter was water leached to determine soluble ion concentrations by ion chromatography (sulphate, nitrate and chloride) and ion selective electrode (ammonium). The remaining $1 / 4$ of each filter was used for the elemental analysis of total carbon (TC) by elemental analyzers. Details of the analytical procedure are given by Querol et al. (2001). Furthermore, OC and EC (organic and elemental carbon) were analyzed by a thermal-optical transmission technique (Birch and Cary, 1996) using a Sunset Laboratory OCEC Analyzer. Moreover, $\mathrm{SiO}_{2}$ and $\mathrm{CO}_{3}^{2-}$ were indirectly determined on the basis of empirical factors $\left(\mathrm{Al}^{*} 1.89=\mathrm{Al}_{2} \mathrm{O}_{3}\right.$, $3^{*} \mathrm{Al}_{2} \mathrm{O}_{3}=\mathrm{SiO}_{2}$ ) mass ratios; see Querol et al. (2001). The indirect determination of $\mathrm{CO}_{3}^{2-}$ levels was obtained according to the output of the ion balance. To this end, for each sam- 
ple the ammonium/sulphate excess was obtained, then ammonium nitrate was calculated. The excess sodium/chloride was calculated and balanced with sulphate and nitrate. The remaining sulphate and nitrate excess was then balanced with calcium, and then the $\mathrm{Ca}$ excess was considered to be calcium carbonate. The addition of the above determinations accounted for $75-85 \%$ of the TSP, $\mathrm{PM}_{10}$ and $\mathrm{PM}_{2.5}$ mass. The chemical components of the PM are grouped as (a) crustal or mineral (sum of $\mathrm{Al}_{2} \mathrm{O}_{3}, \mathrm{SiO}_{2}, \mathrm{CO}_{3}^{2-}, \mathrm{Ca}, \mathrm{Fe}, \mathrm{K}, \mathrm{Mg}, \mathrm{Mn}, \mathrm{Ti}$ and $\mathrm{P}$ ); (b) marine component (sum of $\mathrm{Cl}^{-}$and $\mathrm{Na}^{+}$); (c) organic matter and elemental carbon, $\mathrm{OM}+\mathrm{EC}$ (OM obtained applying a 2.1 factor to the $\mathrm{OC}$ concentrations following the suggestions from Turpin et al., 2001, and Aiken et al., 2008); and (d) secondary inorganic aerosols, SIA (sum of $\mathrm{SO}_{4}^{2-}$, $\mathrm{NO}_{3}^{-}$and $\mathrm{NH}_{4}^{+}$).

\subsubsection{FKL station}

$\mathrm{PM}_{10}$ is routinely monitored at FKL since September 2004, with an Eberline FH 62 I-R (Eberline Instruments $\mathrm{GmbH}$ ) particulate monitor, designed to continuously measure the mass concentration of the suspended particles in ambient air based on b-attenuation (Gerasopoulos et al., 2006). Additional aerosol samples were collected using a Small-Depositarea low-volume-Impactor "SDI" and a Virtual Impactor "VI" (Gerasopoulos et al., 2007; Koulouri et al., 2008) since July 2004. In total, 360 samples (180 PTFE and 180 Quartz filters) have been collected and analyzed for the main anions, cations, elements, OC and EC at different aerosol fractions. The OM/OC ratio was 2.1 as before. PTFE filters were analyzed for water-soluble ions and elements. $1 / 4$ of each PTFEfilter was extracted using $20 \mathrm{ml}$ of pure water $(18 \mathrm{M} \Omega)$. The solutions obtained were analyzed by ion chromatography for anions $\left(\mathrm{Cl}^{-}, \mathrm{Br}^{-}, \mathrm{NO}_{3}^{-}, \mathrm{SO}_{4}^{2-}, \mathrm{C}_{2} \mathrm{O}_{4}^{2-}\right.$, methyl sulfonate) and cations $\left(\mathrm{Na}^{+}, \mathrm{NH}_{4}^{+}, \mathrm{K}^{+}, \mathrm{Mg}^{2+}\right.$ and $\left.\mathrm{Ca}^{2+}\right)$. More details on the IC method are given by Bardouki et al. (2003). Elements ( $\mathrm{Al}, \mathrm{Ti}, \mathrm{V}, \mathrm{Cr}, \mathrm{Mn}, \mathrm{Fe}, \mathrm{Ni}, \mathrm{Cu}, \mathrm{Zn}, \mathrm{Cd}, \mathrm{Pb}$ ) were determined using ICP-MS after acid digestion. Quartz filters were analyzed for organic and elemental carbon (OC and EC), with the same thermal-optical transmission method used at MSY under conditions described in Koulouri et al. (2008).

\subsubsection{ERL station}

At ERL, $\mathrm{PM}_{10-2.5}$ and $\mathrm{PM}_{2.5}$ concentrations were determined gravimetrically from April 2001 to April 2002. Watersoluble ions were measured by ion chromatography (IC) at Environmental Chemical Processes Laboratory (ECPL), University of Crete, following the same method as for FKL filters described in detail by Bardouki et al. (2003). Concentration of the elements $(\mathrm{Fe}, \mathrm{Ti}, \mathrm{Ca}, \mathrm{Mn}, \mathrm{K}, \mathrm{Cr}, \mathrm{V}, \mathrm{Zn}$, $\mathrm{Cl}, \mathrm{S}$ ) were obtained using $2 \mathrm{~cm}^{2}$ of the filter sample applying proton-induced X-ray emission (PIXE) at ATOMKI (Institute of Nuclear Research of the Hungarian Academy of Sciences, Debrecen, Hungary). During the experiments, the aerosol samples were irradiated by a $2 \mathrm{MeV}$ proton beam, which was supplied by the $5 \mathrm{MV}$ Van de Graaff Accelerator of ATOMKI (for more details see Borbely-Kiss et al., 1999). For the evaluation of PIXE spectra, the PIXEKLM software was applied (Szabo and Borbely-Kiss, 1993). BC content in 46 fine aerosol filter samples collected during winter and summer was determined using a smoke stain reflectometer (SSR, Borbely-Kiss et al., 1999). For this purpose, obtained reflectance was converted into $\mu \mathrm{g} \mathrm{m}^{-3}$ by calibrating the instrument using EC (for more details see Koçak et al., 2007a, b). OC data was not available in this station.

\subsection{Complementary analyses}

To interpret the different source regions of air masses, NCEP meteorological maps (Kalnay et al., 1996) and daily backtrajectories calculated by HYSPLIT4 model (Draxler and Rolph, 2003) were used. Daily, 5-day back-trajectories were calculated at 12:00 GMT at receptor points of 700, 1500 and $2500 \mathrm{~m}$ a.s.l. modelling also the vertical velocity. According to these tools, sampling days were classified as African dust outbreaks and transport of marine air masses, from the Atlantic for the WMB and the Mediterranean for both basins. Additionally, in the WMB the recirculation of air masses, the winter anticyclonic episodes, and the transport of European air masses were also identified; whereas for the EMB the air masses from the Central and Northern European continent, were recognized.

African dust outbreaks were additionally identified by aerosol maps from the Marine Meteorology Division of the Naval research Laboratory, USA (NRL) (http://www.nrlmry. navy.mil/aerosol); the SKIRON aerosol concentration maps and simulations (http://forecast.uoa.gr, Kallos et al., 1997); the BSC-/DREAM dust maps (http://www.bsc.es/projects/ earthscience/DREAM/, Pérez et al., 2006); and satellite imagery provided by NASA SeaWIFS project (McClain et al., 1998, http://seawifs.gsfc.nasa.gov/SEAWIFS.html).

\section{Results}

\subsection{PM levels}

Mean annual TSP, $\mathrm{PM}_{10}, \mathrm{PM}_{2.5}$ and $\mathrm{PM}_{1}$ levels recorded at MSY (2002-2008) are 26, 17, 13 and $11 \mu \mathrm{g} / \mathrm{m}^{3}$ (calculated from daily means), whereas at FLK (2004-2008) the mean annual $\mathrm{PM}_{10}, \mathrm{PM}_{2.5}$ and $\mathrm{PM}_{1}$ levels reach 31 , 18 and $10 \mu \mathrm{g} / \mathrm{m}^{3}$ (mean values from SDI 2-day in average samplings) and at ERL (2001-2002) $\mathrm{PM}_{10}$ and $\mathrm{PM}_{2.5}$ attain mean levels of 36 and $10 \mu \mathrm{g} / \mathrm{m}^{3}$. The data shown here, corroborated by the intermediate levels $\left(24 \mu \mathrm{gPM}_{10} / \mathrm{m}^{3}\right)$ measured at a sub-urban site in Palermo by Dongarrà et al. (2007) and the $31 \mu \mathrm{gPM}_{10} / \mathrm{m}^{3}$ (2003-2006) measured at the EMEP site in Cyprus (Ayia Marina, as reported in Airbase), indicate a prominent increase in the annual $\mathrm{PM}_{10}$ levels from WMB to EMB. A north-south gradient of increasing $\mathrm{PM}_{10}$ levels is 
also observed. In the EMB, the mean annual values reported for Lazaropole (Macedonia) and Rojen peak (Bulgaria, airbase dataset) are close to $15 \mu \mathrm{gPM}_{10} / \mathrm{m}^{3}$. The same gradient holds in the WMB when comparing $\mathrm{PM}_{10}$ levels measured at MSY with those recorded at Spanish EMEP stations (Pérez et al., 2008). In both cases, this N-S trend can be explained by the gradual deposition of dust transported from North Africa northwards, as well as the lower rainfall from North to South. Mean annual PM levels at RB sites across the Mediterranean may vary largely year to year mainly because of the influence of the African dust (Querol et al., 2009). In order to minimize the inter-annual variability of this natural contribution we have included the maximum data coverage in this study. As shown in the supplementary information (Table S.1, see http://www.atmos-chem-phys.net/ 9/4575/2009/acp-9-4575-2009-supplement.pdf), most of the selected monitoring sites have 6-7 years of data.

Concerning $\mathrm{PM}_{2.5}, 13,18$ and $10 \mu \mathrm{g} / \mathrm{m}^{3}$, were measured at MSY, FKL and ERL, respectively. This $\mathrm{PM}_{2.5}$ range is slightly higher than the one obtained at RB sites located at Atlantic and Central Spain $\left(8-11 \mu \mathrm{g} / \mathrm{m}^{3}\right)$. As pointed out by Gerasopoulos et al. (2007) the higher values recorded at Finokalia for $\mathrm{PM}_{2.5}$ are due to Saharan dust intrusions. Very close mean annual $\mathrm{PM}_{1}$ levels are measured at MSY and FKL (11 and $10 \mu \mathrm{g} / \mathrm{m}^{3}$, respectively), which is higher than the summer levels measured at Monte Cimone in Italy (7 $\mu \mathrm{g} / \mathrm{m}^{3}$, Marenco et al., 2006), which is a free tropospheric site (2165 $\mathrm{m}$ a.s.1.).

As $\mathrm{PM}_{10}$ and $\mathrm{PM}_{2.5}$ are influenced by dust sources, prominent $\mathrm{W}-\mathrm{E}$ and $\mathrm{N}-\mathrm{S}$ gradients are also revealed for the different $\mathrm{PM}$ fraction ratios. Thus, $\mathrm{PM}_{2.5} / \mathrm{PM}_{10}$ reaches the lowest values in the EMB (0.3-0.6 at FKL and ERL), similar to the Canary Islands and southern Iberian Peninsula ( 0.4 and 0.5, respectively, Querol et al., 2004, 2008). In the Central and Northern Iberian Peninsula, the average $\mathrm{PM}_{2.5} / \mathrm{PM}_{10}$ ratio ranges between 0.60 and 0.75 . The same tendency is also seen in the mean $\mathrm{PM}_{1} / \mathrm{PM}_{2.5}$ ratios ranging from 0.65 at $\mathrm{FKL}$ to 0.8 at MSY.

\subsubsection{Diurnal variability of PM levels}

The daily evolution of PM levels (Fig. 2) at semi-elevated sites of the WMB, such as MSY, depends strongly on the dominant breeze circulation (mountain and sea breezes) (Pérez et al., 2008). More precisely, early in the day atmospheric pollutants are accumulated in the pre-coastal depression (highly populated and industrialized, crossed by important main roads); subsequently the diurnal breeze development (activated by insolation) increases PM levels at MSY by transporting the aged air masses upwards from the valley. The cleaner nocturnal drainage flows and the decrease in the mixing layer height decreases the PM levels, representing the continental background.

Thus during night (20:00-06:00 GMT), relatively low PM levels are recorded, and the mean continental background
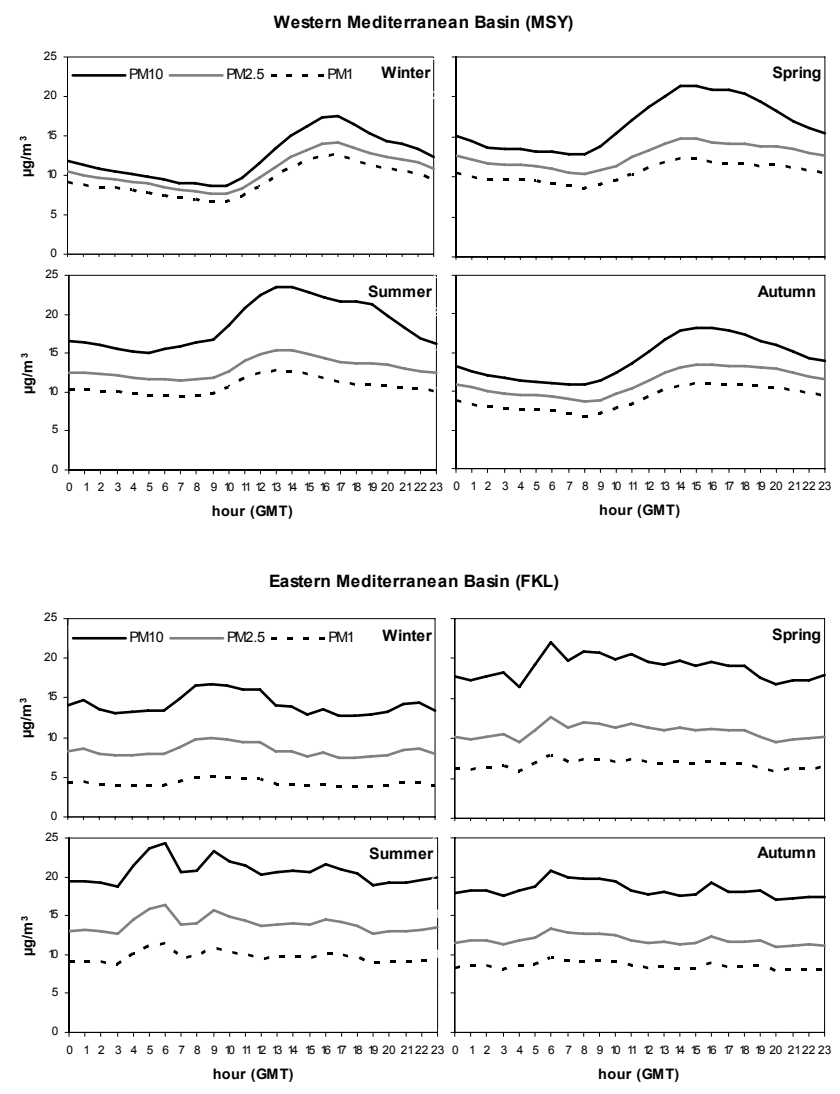

Fig. 2. Mean seasonal daily evolution of $\mathrm{PM}_{10}, \mathrm{PM}_{2.5}$ and $\mathrm{PM}_{1}$ levels in the WMB (MSY) and EMB (FKL). Note that the $\mathrm{PM}_{2.5}$ and $\mathrm{PM}_{1}$ daily levels at FKL have been calculated from the $\mathrm{PM}_{1} / \mathrm{PM}_{10}$ and $\mathrm{PM}_{2.5} / \mathrm{PM}_{10}$ ratios.

levels for the study period are estimated at 12,9 and $6 \mu \mathrm{g} / \mathrm{m}^{3}$ for $\mathrm{PM}_{10}, \mathrm{PM}_{2.5}$ and $\mathrm{PM}_{1}$, in winter and 15,12 and $9 \mu \mathrm{g} / \mathrm{m}^{3}$ in summer.

From early morning (06:00-08:00 GMT in summer, 09:00-10:00 GMT in winter) to afternoon, PM levels increase progressively in coincidence with the southern flow, reaching maximum values between 13:00-14:00 GMT in summer and 15:00-16:00 GMT in winter (Fig. 2). Mean maximum hourly values of 20,16 and $13 \mu \mathrm{g} / \mathrm{m}^{3}$ in winter and 23,16 and $13 \mu \mathrm{g} / \mathrm{m}^{3}$ in summer are registered for $\mathrm{PM}_{10}$, $\mathrm{PM}_{2.5}$ and $\mathrm{PM}_{1}$, respectively.

In the EMB, and in particular at the remote coastal FKL station, PM levels are highly impacted by the year-round presence of dust from North Africa. This is evidenced by the significant deviation between average and median hourly values when calculating the typical PM diurnal cycle (not shown here). To diminish the random contribution of dust on the mean PM diurnal cycle, that inhibits revealing the processes that control the diurnal cycle, we have used medians of hourly values, additionally excluding concentrations $>50 \mu \mathrm{g} / \mathrm{m}^{3}$ for $\mathrm{PM}_{10}$ (Fig. 2). In any case it is noticeable the lower diurnal/nocturnal PM contrast in the EMB and FKL 
compared with the MSY. This may be due in our study to the influence of large regional emissions of atmospheric pollutants transported to MSY by mountain and seas breezes during daytime. In the absence of high resolution data for $\mathrm{PM}_{2.5}$ and $\mathrm{PM}_{1}$, we have used the ratios of $\mathrm{PM}_{1} / \mathrm{PM}_{10}$ and $\mathrm{PM}_{2.5} / \mathrm{PM}_{10}$ derived from the impactors for each season, to reproduce their mean diurnal cycle, keeping in mind that in this way we force their pattern to follow the respective one of $\mathrm{PM}_{10}$.

As in the case of WMB, relatively lower PM levels are encountered during night (20:00-04:00 GMT). The mean continental background levels for the study period are estimated at 14,8 and $4 \mu \mathrm{g} / \mathrm{m}^{3}$ for $\mathrm{PM}_{10}, \mathrm{PM}_{2.5}$ and $\mathrm{PM}_{1}$, in winter, and 19,13 and $9 \mu \mathrm{g} / \mathrm{m}^{3}$ in summer. A progressive PM level enhancement is observed during daytime, however with different characteristics for each season. In summer two morning peaks are found (Fig. 2) at 04:00-6:00 GMT and 08:00-10:00 GMT, the first one coinciding with an increase of $\mathrm{NO}_{\mathrm{x}}$, and probably attributed to anthropogenic emissions; and the second one associated to an increase in ozone, possibly demonstrating the effect of regional sources of pollution under intense photochemical activity (Gerasopoulos et al., 2005). During the transitional seasons (spring and autumn), daytime enhanced PM levels are still evident, however the role of photochemical processes appears less significant. Finally, in winter, the peak narrows and is delimited between 05:00 and 11:00 GMT, possibly reflecting the conjunction of diurnal patterns of otherwise lower levels of pollution and solar radiation. Mean maximum hourly values of 17, 10 and $5 \mu \mathrm{g} / \mathrm{m}^{3}$ in winter and of 24,16 and $11 \mu \mathrm{g} / \mathrm{m}^{3}$ in summer are registered for $\mathrm{PM}_{10}, \mathrm{PM}_{2.5}$ and $\mathrm{PM}_{1}$, respectively. The similarity of the mean maximum summer values between FKL and MSY and the large differences found in winter are attributed to the high summer atmospheric mixing, and the effect of the winter anticyclonic episodes frequently developed in the WMB.

\subsubsection{Seasonal variability of PM levels}

The seasonal and multi-year evolution of $\mathrm{PM}_{10}$ levels at MSY, FKL and ERL is presented in Fig. 3. A clear summer maximum in the WMB and a broader or bimodal pattern in the EMB, depending on the relative contribution of anthropogenic and natural aerosols, are observed.

Indeed, in the WMB the highest levels are registered during summer months (June and July), associated with the higher frequency of African dust outbreaks, lower precipitation, higher resuspension due to soil dryness, increased formation of secondary aerosols (Fig. 4) and recirculation of air masses that prevent air renovation (Querol et al., 2001; Viana et al., 2002; Escudero et al., 2005). The summer increase is more pronounced in the coarse fraction $\left(\mathrm{PM}_{2.5-10}\right)$ than in the finer fractions $\left(\mathrm{PM}_{1-2.5}\right.$ and $\left.\mathrm{PM}_{1}\right)$ because of the coarser size of the mineral dust and summer-nitrate particles (Fig. 4, Pérez et al., 2008). During the rest of the year, PM levels are relatively low owing to the high frequency of Atlantic ad- vections and precipitation. A secondary maximum is found during winter (November to March) when PM levels rise because of intense pollution episodes of either anthropogenic (winter anticyclonic scenarios) or natural (African dust) origins. The seasonal variation of PM levels at MSY is also influenced by the evolution of the boundary layer. When the monitoring site is outside the boundary layer (especially in winter), it is less affected by regional anthropogenic emissions, in contrast to summer.

In the EMB the higher frequency of dust episodes in spring (Moulin et al., 1998) has a significant contribution to local RB-PM levels. Indeed, the seasonal maximum is usually recorded in spring (April-May) as a consequence of the frequent African dust episodes, which actually exceeds the summer maximum. This is clearly evident in the coarser fractions $\left(\mathrm{PM}_{10}\right.$ or even $\left.\mathrm{PM}_{2.5}\right)$ while for $\mathrm{PM}_{1}$ a secondary summer maximum is observed, in accordance to the seasonality of anthropogenic types of aerosols like non-sea salt sulphate (Gerasopoulos et al., 2007; Koulouri et al., 2008).

\subsection{PM speciation}

In relative proportions (Fig. 5), mineral matter is the major component of $\mathrm{PM}_{10}$ at both $\mathrm{W}$ and EMBs (22 to 38\%, with the higher proportions being obtained at the EMB), followed by sulphate, OM, nitrate and ammonium. Sea spray shows a marked variation with a clear increasing trend towards the EMB, especially in the coastal sites, where it may reach significant levels to become a major component of $\mathrm{PM}_{10}$. As expected, in $\mathrm{PM}_{2.5}$, the relative proportions of crustal and sea spray components decreased when compared with $\mathrm{PM}_{10}$. However the proportions of crustal material were relatively high in $\mathrm{PM}_{2.5}$ (8 to 14\%). Conversely, the proportion of all the other components increased. Around 10 to $14 \%$ of the $\mathrm{PM}_{10}$ mass (and 2 to $16 \%$ of the $\mathrm{PM}_{2.5}$ ) consists of unaccounted mass, which is mainly attributed to moisture not eliminated during filter conditioning. A number of inorganic hetero-atoms $(\mathrm{F}, \mathrm{O}, \mathrm{H})$, not analyzed here, may also be responsible for a small fraction of this unaccounted proportion.

The comparison of WMB and EMB with North and Central Europe, in terms of composition, show major gradients of crustal, nitrate, sulphate, OC and EC. Figures 1 and 6 (and also Table S.2, from supplementary information: http://www.atmos-chem-phys.net/9/4575/2009/ acp-9-4575-2009-supplement.pdf) show the mean levels of $\mathrm{PM}_{10}$ and $\mathrm{PM}_{2.5}$ components measured at MSY, FKL and ERL and a selection of rural-RB sites.

The main distinctive feature of PM at the three sites of this study is the relatively high levels of the crustal component (4 and $1 \mu \mathrm{g} / \mathrm{m}^{3}$ for $\mathrm{PM}_{10}$ and $\mathrm{PM}_{2.5}$ at MSY; 14 and 2 ( 0.8 if the major 6 dust events are removed) $\mu \mathrm{g} / \mathrm{m}^{3}$ for $\mathrm{PM}_{10}$ and $\mathrm{PM}_{1}$ at $\mathrm{FKL}$; and 9 , and $1 \mu \mathrm{g} / \mathrm{m}^{3}$ for $\mathrm{PM}_{10}$ and $\mathrm{PM}_{2.5}$ at ERL, respectively) when compared with the selected central and northern European sites ( 2 and $<0.5 \mu \mathrm{g} / \mathrm{m}^{3}$ for $\mathrm{PM}_{10}$ and $\mathrm{PM}_{2.5}$ in most cases). The accessional year round con- 

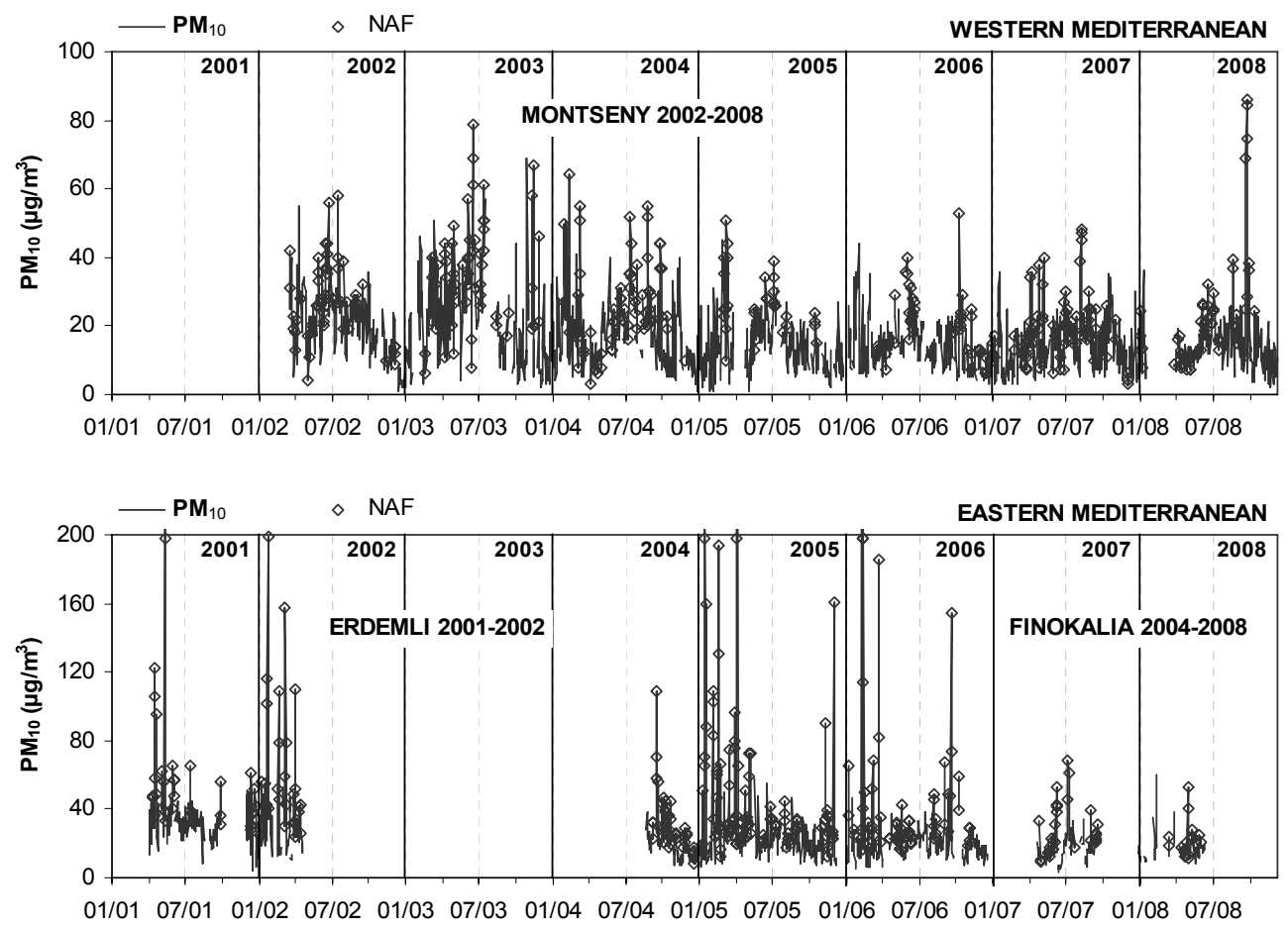

Fig. 3. Mean daily $\mathrm{PM}_{10}$ levels from 2001 to 2008 at Montseny (WMB), and Erdemli and Finokalia (EMB). African dust episodes are indicated with unfilled rhombus.

tribution of dust at FKL is estimated to be $8 \pm 5 \mu \mathrm{gPM} 10 / \mathrm{m}^{3}$, in agreement with the range given by Mitsakou et al. (2008) $\left(5-9 \mu \mathrm{g} / \mathrm{m}^{3}\right)$ for Heraklion, the nearest large city to FKL station. Of course, at the remote site of FKL the percentage contribution of dust is much higher than at Heraklion reaching $40-50 \%$ in spring (frequent dust outbreaks) and winter (some of which are among the most intense events). In the WMB this African dust annual contribution ranges from 1$2 \mu \mathrm{gPM}_{10} / \mathrm{m}^{3}$ in the NWMB to $7 \mu \mathrm{gPM}_{10} / \mathrm{m}^{3}$ in the SWMB.

Sulphate levels measured at WMB-MSY $\left(3 \mu \mathrm{g} / \mathrm{m}^{3}\right)$ fall in the usual range reported for rural-RB sites in central and southern Europe and the UK $\left(2-4 \mu \mathrm{g} / \mathrm{m}^{3}\right)$, and are higher than those measured at RB sites of Switzerland and the Scandinavian region $\left(1-2 \mu \mathrm{g} / \mathrm{m}^{3}\right)$. However, at the EMB-FKLERL, measured levels are among the highest in Europe (5$\left.6 \mu \mathrm{g} / \mathrm{m}^{3}\right)$. EMB is highly influenced by air masses coming from Eastern Europe (e.g. Ukraine, Russia) which in association with high insolation in the area favours $\mathrm{H}_{2} \mathrm{SO}_{4}$ production via homogeneous reactions (Mihalopoulos et al., 2007). Furthermore, $\mathrm{SO}_{2}$ emissions from coal power generation in Greece and the countries surrounding the Black Sea, the latter contributing to more than one third of the total $\mathrm{SO}_{2}$ emissions reported over Europe in 2004 (Vestreng et al., 2007), may also contribute to enhanced sulphate levels in EMB. Furthermore, the high levels of sulphate in the EMB deplete the available gas-phase $\mathrm{NH}_{3}$ so that little ammonium nitrate can form due to the low $\mathrm{NH}_{3}$ levels. Note that this is consistent with the aerosols in the EMB being acidic and those in the WMB being neutralized by $\mathrm{NH}_{4}^{+}$, as later discussed.
Nitrate and ammonium levels at both WMB and EMB follow a very similar spatial distribution pattern. For instance nitrate levels range from 1.7 to $1.9 \mu \mathrm{g} / \mathrm{m}^{3}$ at both basins. These values are lower than in central Europe and the UK $\left(2-4 \mu \mathrm{g} / \mathrm{m}^{3}\right)$, slightly higher than at RB sites of Switzerland and the Scandinavian region $\left(0.5-1 \mu \mathrm{g} / \mathrm{m}^{3}\right)$ and similar to the levels measured in RB sites of Italy.

Concerning SIA, the nitrate/sulphate ratio in $\mathrm{PM}_{10}$ in the WMB is in the range of $0.4-0.6$ for most years, whereas in the EMB, this ratio falls in the lowest fraction of the above range (0.3-0.4), close to the range of values reported for $\mathrm{RB}$ sites of Switzerland and Scandinavia (Birkenes) and almost half the values recorded in RB sites of Germany and UK (Table S.2, from supplementary information).

Finally, a very interesting difference between the size distributions of nitrate was observed. In central and northern Europe and in the WMB the ratio of nitrate levels in $\mathrm{PM}_{2.5} / \mathrm{PM}_{10}$ is constantly 0.7 to 0.8 , whereas in the EMB this decreases down to $0.1-0.2$ (see also $\mathrm{PM}_{2.5}$ data measured at Patras; Table S2). This is probably due to several factors, such as: 1) the major occurrence of coarse sodium and calcium nitrate in the EMB (also in an important proportion in the WMB) with respect to other areas, and 2) with a minor relevance, the high levels of sulphate in EMB, sufficient to neutralize ammonium and consequently reduce ammonium nitrate formation under favouring meteorological conditions i.e. during winter. 


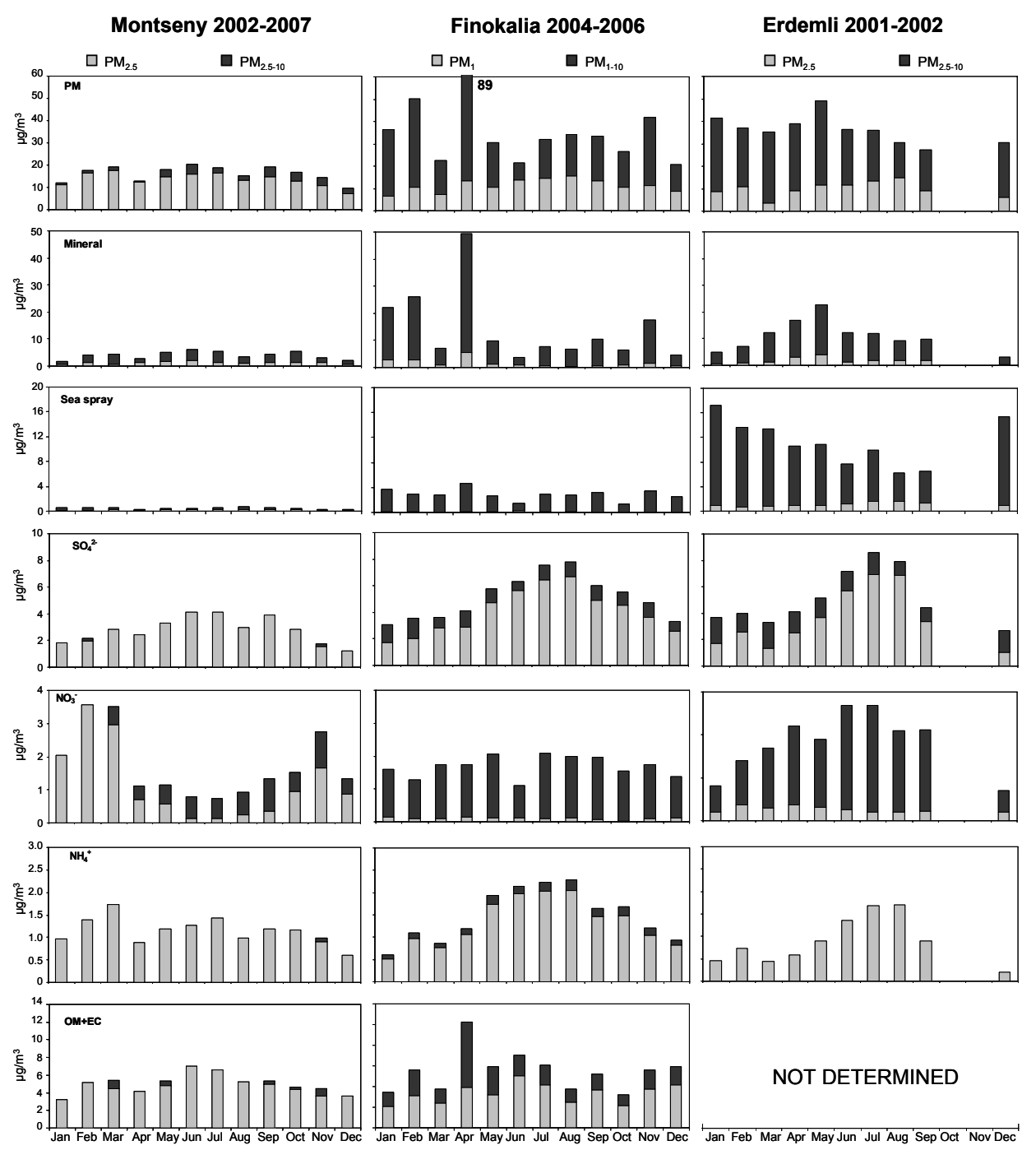

Fig. 4. Seasonal evolution of PM mass concentration and its major species (mineral dust, sea spray, sulphate, nitrate, ammonium and organic matter + elemental carbon) in $\mathrm{PM}_{2.5}$ and $\mathrm{PM}_{2.5-10}$ (Montseny and Erdemli) or $\mathrm{PM}_{1}$ and $\mathrm{PM}_{1-10}$ (Finokalia).

$E C$ and $O M$ levels are also homogeneous across the $\mathrm{RB}$ of the Mediterranean $\left(0.2-0.4\right.$ and $5-6 \mu \mathrm{g} / \mathrm{m}^{3}$ respectively) and lower compared to most RB sites of central Europe (Putaud et al., 2004; Pio et al., 2007). It has to be noted that as shown in Fig. 4, at FKL significant coarse $\mathrm{OM}+\mathrm{EC}$ were measured. This is not the case of MSY, where most of OM + EC are in the fine mode. High concentrations of these species in the coarse mode are unusual but we do not have a major explanation for it. The OC/EC ratio mean values are close to 11 at MSY and 4 at FLK. The highest ratio in the WMB may be attributed to the significant SOA formation from biogenic volatile organic compounds (VOCs) (Peñuelas et al., 1999), anthropogenic VOCs (from road traffic, power generation, among others), and VOCs emitted by biomass burning, enhanced by the lack of ventilation in spring-summer and the higher photochemical activity. Formation of SOA from anthropogenic precursors has been shown to be a major cause of increased PM levels in many regions of the World, but it appears to be underestimated by current models (Volkamer et al., 2006). The high OC/EC ratios measured at MSY can be explained by the high SOA formation from a combination of biogenic and anthropogenic precursors, and also biomass burning emissions (Reid et al., 2005; Hallquist et al., 2009).

Levels of sea spray $\left(0.5\right.$ and $0.2 \mu \mathrm{g} / \mathrm{m}^{3}$ for $\mathrm{PM}_{10}$ and $\mathrm{PM}_{2.5}$ at MSY; 2.9 and $0.1 \mu \mathrm{g} / \mathrm{m}^{3}$ for $\mathrm{PM}_{10}$ and $\mathrm{PM}_{1}$ at $\mathrm{FKL}$; and 8.9 and $0.4 \mu \mathrm{g} / \mathrm{m}^{3}$ for $\mathrm{PM}_{10}$ and $\mathrm{PM}_{2.5}$ at ERL, the later being located a few meters from the shore-line) vary strongly across WMB and EMB, being usually much lower in the WMB. In the WMB sea spray is low $\left(<1 \mu \mathrm{g} / \mathrm{m}^{3}\right.$ in $\left.\mathrm{PM}_{10}\right)$ in the mountainous areas surrounding the Mediterranean, such as MSY. At the coastal areas the levels are higher (annual average around $4 \mu \mathrm{g} / \mathrm{m}^{3}$ in $\mathrm{PM}_{10}$ at the Balearic Islands), but lower when compared with the Atlantic sites of Europe (4 to $12 \mu \mathrm{g} / \mathrm{m}^{3}$, Visser et al., 2001; Querol et al., 2004). 

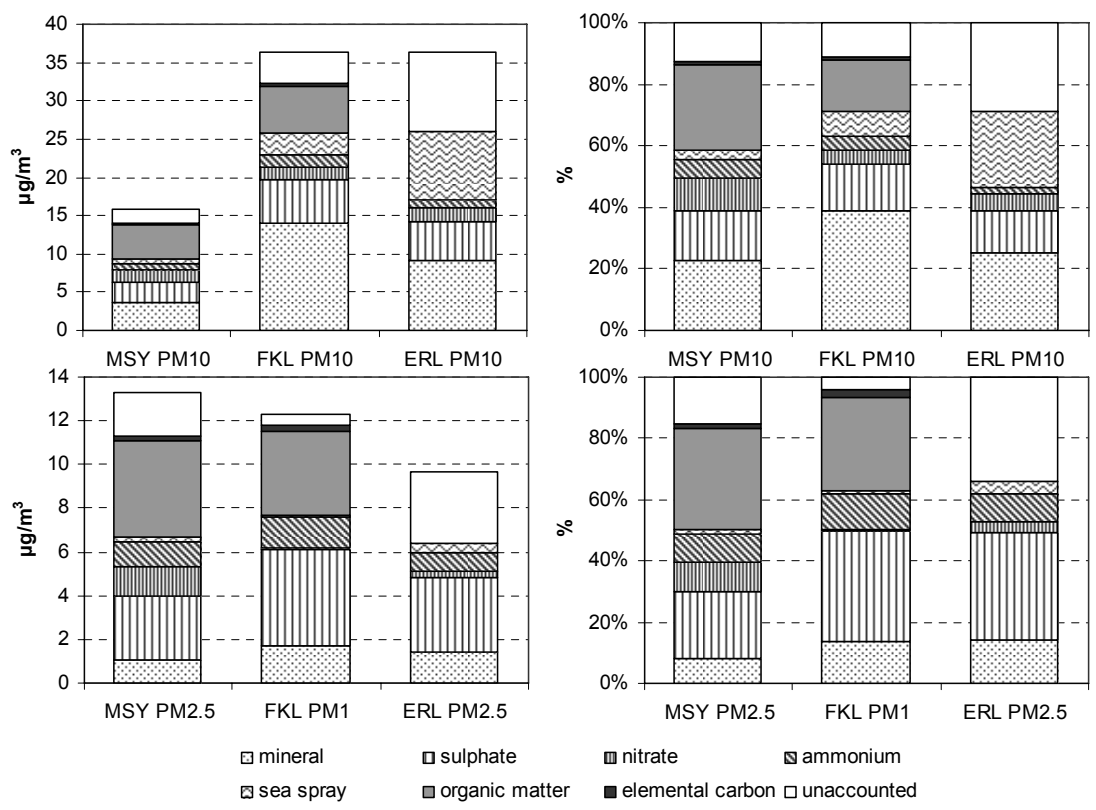

Fig. 5. PM major composition $\left(\mu \mathrm{g} / \mathrm{m}^{3}\right.$ and \%) at Montseny (MSY) and Erdemli (ERL) in $\mathrm{PM}_{10}$ and $\mathrm{PM}_{2.5}$, and Finokalia (FKL) in PM 10 and $\mathrm{PM}_{1}$.

Table 1 shows the mean levels of trace elements analyzed in $\mathrm{PM}_{10}$ and $\mathrm{PM}_{2.5}$ at MSY, ERL, FKL and a selection of rural-RB sites. Levels of $\mathrm{V}$ and $\mathrm{Ni}$ measured at both basins are higher (by a factor of 3 to 9) than most sites in central Europe possibly as a consequence of the relatively high emissions from fuel-oil combustion (power generation, industrial and shipping emissions). The other elements analyzed fall in similar concentration ranges.

Overall, based on the above characteristics it may be concluded that EMB compared to WMB is characterized by higher levels of crustal material and sulphate. Furthermore, $\mathrm{Na}$ and $\mathrm{Ca}$ nitrate are the main species of nitrate in the EMB in contrast to the prevalence of $\mathrm{NH}_{4}^{+}$-nitrate in the WMB. Compared to European sites of similar characteristics, all Mediterranean sites are characterized by relatively high levels of crustal material and lower levels of $\mathrm{OM}+\mathrm{EC}$ and nitrate (Table S.2).

\subsubsection{Seasonal variability of PM chemical composition}

The major PM chemical components show marked seasonal trends in the W and EMBs (Fig. 4).

Mineral matter in $\mathrm{PM}_{10}$ and $\mathrm{PM}_{2.5}$ exhibits strong seasonal variability and high levels almost throughout the year at both W and EMBs (Fig. 4). This fact can be attributed to both the elevated dust resuspension of local and regional origin due to high convective dynamics and low rainfall, and the higher frequency of African dust episodes occurring during spring and autumn in the EMB and spring and summer in the WMB (Pérez et al., 2008). The levels of mineral matter in $\mathrm{PM}_{2.5}$ usually account for less than $50 \%$ of those measured for $\mathrm{PM}_{10}$, although this ratio varies throughout the year. In the WMB the lowest ratio of the $\mathrm{PM}_{2.5} / \mathrm{PM}_{10}$ mineral matter is measured from late spring to mid summer (20-30\%), and the highest in winter (35-45\%). However, this does not occur in the EMB where the ratio remains constantly low (around $15 \%$ ) throughout the year, indicating the presence of coarser particles.

Nitrate levels at MSY present a strong seasonal variability with higher values during colder months and much reduced levels in the warmer period (Fig. 4), owing to the thermal instability of the ammonium nitrate (Harrison and Pio, 1983; Querol et al., 2004), the most frequent compound of nitrate at this site. Nevertheless, the occurrence of a relatively high proportion of coarse nitrate species $(\mathrm{Ca}$ and $\mathrm{Na}$ nitrate compounds) can be also deduced from the MSY data as the ratio of $\mathrm{PM}_{2.5} / \mathrm{PM}_{10}$ nitrate is very close to $90 \%$ during the colder months and around $20 \%$ in summer. It is important to highlight that extremely intense nitrate episodes are recorded every year from November to March (up to $15 \mu \mathrm{g} / \mathrm{m}^{3}$ of daily mean nitrate levels, Fig. 5) being associated with the transport (by mountain breezes) of aged air masses from the surrounding industrial/urban areas during anticyclonic scenarios (Pérez et al., 2008). At the EMB the situation regarding nitrate is completely different as nitrate presents higher values during summer and lower during winter. Size-segregated measurements show that the majority of nitrate $(>85 \%)$ is confined in the coarse mode, strongly indicating that it is chemically combined mostly with alkaline ion species (Mamane and Gottlieb, 1992; Pakkanen et al., 1999). The most likely formation pathway for particulate nitrate $\left(\mathrm{NO}_{3}^{-}\right)$is the reaction of gaseous nitric acid or some other nitrogen compounds with sea salt particles and mineral dust particles (Metzger et al., 2006). 
Table 1. Mean levels of trace elements analyzed in $\mathrm{PM}_{10}$ and $\mathrm{PM}_{2.5}$ at MSY, FKL and ERL and a selection of rural-regional background sites.

\begin{tabular}{|c|c|c|c|c|c|c|c|c|c|c|c|c|c|c|c|c|c|c|c|}
\hline & \multirow{3}{*}{$\begin{array}{c}\text { USA } \\
\text { Sterling } \\
\text { Forest }^{1} \\
\mathrm{PM}_{2.5}\end{array}$} & \multirow{2}{*}{\multicolumn{2}{|c|}{$\begin{array}{c}\text { Austria } \\
\text { Streithofen }{ }^{2}\end{array}$}} & \multicolumn{3}{|c|}{ Switzerland } & \multicolumn{2}{|c|}{ Italy } & \multicolumn{7}{|c|}{ Spain } & \multicolumn{2}{|c|}{ Greece } & \multicolumn{2}{|c|}{ Turkey } \\
\hline & & & & \multirow{2}{*}{$\begin{array}{c}\text { Payerne }^{3} \\
\mathrm{PM}_{10}\end{array}$} & \multicolumn{2}{|c|}{ Chaumont $^{3}$} & \multicolumn{2}{|c|}{ Mt Cimone ${ }^{4}$} & \multicolumn{2}{|c|}{ Bemantes $^{5}$} & \multicolumn{2}{|c|}{ Villar Arzobispo $^{6}$} & \multirow{2}{*}{$\begin{array}{c}\text { Monagrega }^{7} \\
\mathrm{PM}_{10}\end{array}$} & \multicolumn{2}{|c|}{ Montseny } & \multicolumn{2}{|c|}{ FKL } & \multicolumn{2}{|c|}{$\mathrm{ERL}^{8}$} \\
\hline & & $\mathrm{PM}_{10}$ & $\mathrm{PM}_{2.5}$ & & $\mathrm{PM}_{10}$ & $\mathrm{PM}_{2.5}$ & $\mathrm{PM}_{10}$ & $\mathrm{PM}_{1}$ & $\mathrm{PM}_{10}$ & $\mathrm{PM}_{2.5}$ & $\mathrm{PM}_{10}$ & $\mathrm{PM}_{2.5}$ & & $\mathrm{PM}_{10}$ & $\mathrm{PM}_{2.5}$ & $\mathrm{PM}_{10}$ & $\mathrm{PM}_{1}$ & $\mathrm{PM}_{10}$ & $\mathrm{PM}_{2.5}$ \\
\hline $\mathrm{Li}$ & & & & & & & & & 0.1 & 0.1 & 0.3 & 0.2 & & 0.2 & 0.1 & & & & \\
\hline V & 3 & 1 & 1 & 1 & 1 & 1 & 3 & & 5 & 4 & 3 & 3 & 2 & 4 & 3 & 8 & 5 & 9 & 5 \\
\hline $\mathrm{Cr}$ & & 0.5 & 0.3 & & & & & & 1 & 1 & 2.1 & 2 & 1 & 1 & 0.9 & 9 & 3 & 5.7 & 1.8 \\
\hline $\mathrm{Mn}$ & 1 & 4 & 2 & 3 & 2 & 1 & 6 & & 5 & 3 & 4 & 3 & 5 & 5 & 3 & 12 & 2 & 8 & 2 \\
\hline Co & & 0.004 & 0.003 & & & & & & 0.1 & 0.2 & 0.1 & 0.1 & & 0.1 & 0.1 & & & & \\
\hline $\mathrm{Ni}$ & 4 & 1 & 0 & 1 & 1 & 1 & 1 & & 3 & 4 & 3 & 4 & & 2 & 2 & 4 & 2 & 4 & 2 \\
\hline $\mathrm{Cu}$ & 1 & 4 & 2 & 6 & 7 & 6 & 3 & & 8 & 9 & 2 & 1 & 3 & 5 & & 3 & 2 & & \\
\hline $\mathrm{Ga}$ & & & & 0.03 & 0.04 & 0.02 & & & 0.2 & 0.1 & 0.07 & 0.07 & & 0.1 & 0.1 & & & & \\
\hline As & & 0.7 & 0.5 & 0.5 & 0.2 & 0.2 & & & 0.4 & 0.3 & 0.2 & 0.3 & & 0.3 & 0.3 & & & & \\
\hline $\mathrm{Zn}$ & 9 & 27 & 17 & & & & 10 & 6 & 16 & 17 & 11 & 12 & 30 & 12 & & 29 & 12 & 10 & 5 \\
\hline $\mathrm{Se}$ & 1.0 & & & 0.2 & 0.2 & 0.2 & & & 0.5 & 0.4 & 0.3 & 0.4 & & 0.3 & 0.2 & & & & \\
\hline $\mathrm{Sr}$ & 1 & & & & & & 3 & & 1 & 1 & 1 & 1 & 5 & 2 & 1 & & & & \\
\hline $\mathrm{Ba}$ & 0 & & & & & & & & 6 & 5 & 4 & 5 & & 6 & 4 & & & & \\
\hline $\mathrm{Pb}$ & 2 & 17 & 12 & 10 & 5 & 5 & 4 & 2 & 8 & 7 & 5 & 6 & 10 & 4 & 5 & 9 & 6 & & \\
\hline $\mathrm{Rb}$ & & & & 0.3 & 0.3 & 0.2 & & & 1 & 0.5 & 0.5 & 0.5 & & 0.5 & 0.2 & & & & \\
\hline $\mathrm{Y}$ & & & & 0.04 & 0.04 & 0.01 & & & 0.1 & 0.1 & 0.07 & 0.05 & & 0.1 & 0.1 & & & & \\
\hline $\mathrm{Cd}$ & & 0.3 & 0.2 & 0.3 & 0.1 & 0.1 & & & 0.2 & 0.2 & 0.1 & 0.1 & & 0.1 & 0.1 & & & & \\
\hline $\mathrm{Sb}$ & & & & 0.3 & 0.2 & 0.2 & & & 0.6 & 0.4 & 0.4 & 0.3 & & 0.5 & 0.4 & & & & \\
\hline $\mathrm{La}$ & & & & 0.1 & 0.1 & 0.2 & & & 0.1 & 0.1 & 0.1 & 0.1 & & 0.2 & 0.1 & & & & \\
\hline $\mathrm{Ce}$ & & & & & & & & & 0.2 & 0.2 & 0.2 & 0.2 & & 0.4 & 0.2 & & & & \\
\hline $\mathrm{Tl}$ & & & & 0.03 & 0.01 & 0.01 & & & 0.1 & 0.1 & 0.1 & 0.2 & & 0.1 & 0.1 & & & & \\
\hline Sn & & & & & & & & & 0.5 & 0.4 & 0.4 & 1 & & 1 & 1 & & & & \\
\hline
\end{tabular}

${ }^{1}$ Lall and Thrurston (2006); ${ }^{2}$ Puxbaum et al. (2004); ${ }^{3}$ Hueglin et al. (2005); ${ }^{4}$ Marenco et al. (2006); ${ }^{5}$ Salvador et al. (2007); ${ }^{6}$ Viana et al. (2008); ${ }^{7}$ Rodriguez et al. (2004).

Sulphate levels at both basins increase progressively from April-May to reach maximum levels in mid summer (Fig. 4). This seasonal pattern could be related to enhanced photochemistry, low air mass renovation at regional scale, the increment of the summer mixing layer depth favouring the regional mixing of polluted air masses, and possible higher summer contribution of marine secondary sulphate from DMS oxidation (Millán et al., 1997; Rodríguez et al., 2002; Mihalopoulos et al., 2007). In the WMB secondary maxima of sulphate concentration are commonly recorded from November to March, coinciding with the anticyclonic nitrate pollution episodes. At both basins, sulphate species have a prevalent fine grain size (ratio $\mathrm{PM}_{2.5} / \mathrm{PM}_{10}$ close to 1 ) without significant variations in grain size throughout the year. Only a small proportion of coarse $\mathrm{SO}_{4}^{2-}$ is observed during African dust outbreaks, probably due to the formation of $\mathrm{CaSO}_{4}$.

Ammonium concentration shows different behaviour in each basin. In the WMB only slight variations throughout the year are observed with mainly three peaks appearing. Two of them in the colder months are related with the presence of ammonium nitrate (and in lower proportion ammonium sulphate) and another one in summer is associated with the highest concentration of ammonium sulphate. During April-May and September-October minimum levels are generally recorded. Due to the artefact reaction between the ammonium nitrate and sodium chloride on $\mathrm{PM}_{10}$ filters, and the consequent loss of gaseous ammonium chloride (Querol et al., 2001), higher levels of ammonium were on average recorded in $\mathrm{PM}_{2.5}$ with respect to those obtained in $\mathrm{PM}_{10}$. Sodium chloride is mainly retained in the $\mathrm{PM}_{2.5}$ cyclone and the interaction of these species with ammonium nitrate in the filter is prevented. However, in $\mathrm{PM}_{10}$, the two species may interact on the filter.

At the EMB, as only formation of ammonium sulphate occurs, ammonium follows the seasonal variation of sulphate. The significant correlation between $\mathrm{NH}_{4}^{+}$and nss- $\mathrm{SO}_{4}^{2-}$ observed both at ERL and FKL, with the equivalent $\mathrm{NH}_{4}^{+}$/nss$\mathrm{SO}_{4}^{2-}$ slope being smaller than 1 (0.85 in FKL and 0.64-0.95

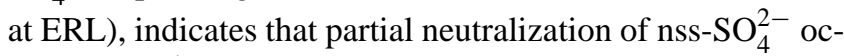
curs by $\mathrm{NH}_{4}^{+}$.

Sea spray presents no uniform behaviour in the MB. In particular, at MSY it shows a distinct seasonal trend (Fig. 4), with highest concentration during summer, probably related to the increasing sea breeze circulation over the coast (located at $30 \mathrm{~km}$ ), which intensifies in the mid summer. On the contrary, no clear trend is observed at FKL, while at ERL a maximum is found during winter. However, at both locations sea spray clearly follows the wind speed variation. At both basins chlorine/sodium ratios show a seasonal trend, with higher winter values (close to the typical marine ratio) and considerably lower values in summer. The lower summer ratios may be attributed to interaction of nitric acid with abundant sodium chloride which causes loss of volatile hydrochloric acid. As expected, sea spray had a prevalent coarse grain size, with constant $\mathrm{PM}_{2.5} / \mathrm{PM}_{10}$ ratios in the range $0.4-0.6$. 

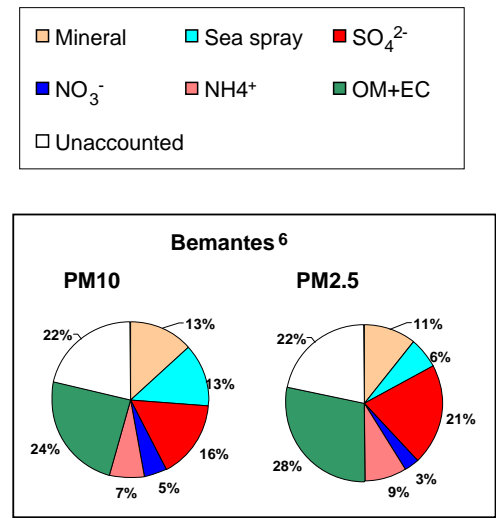
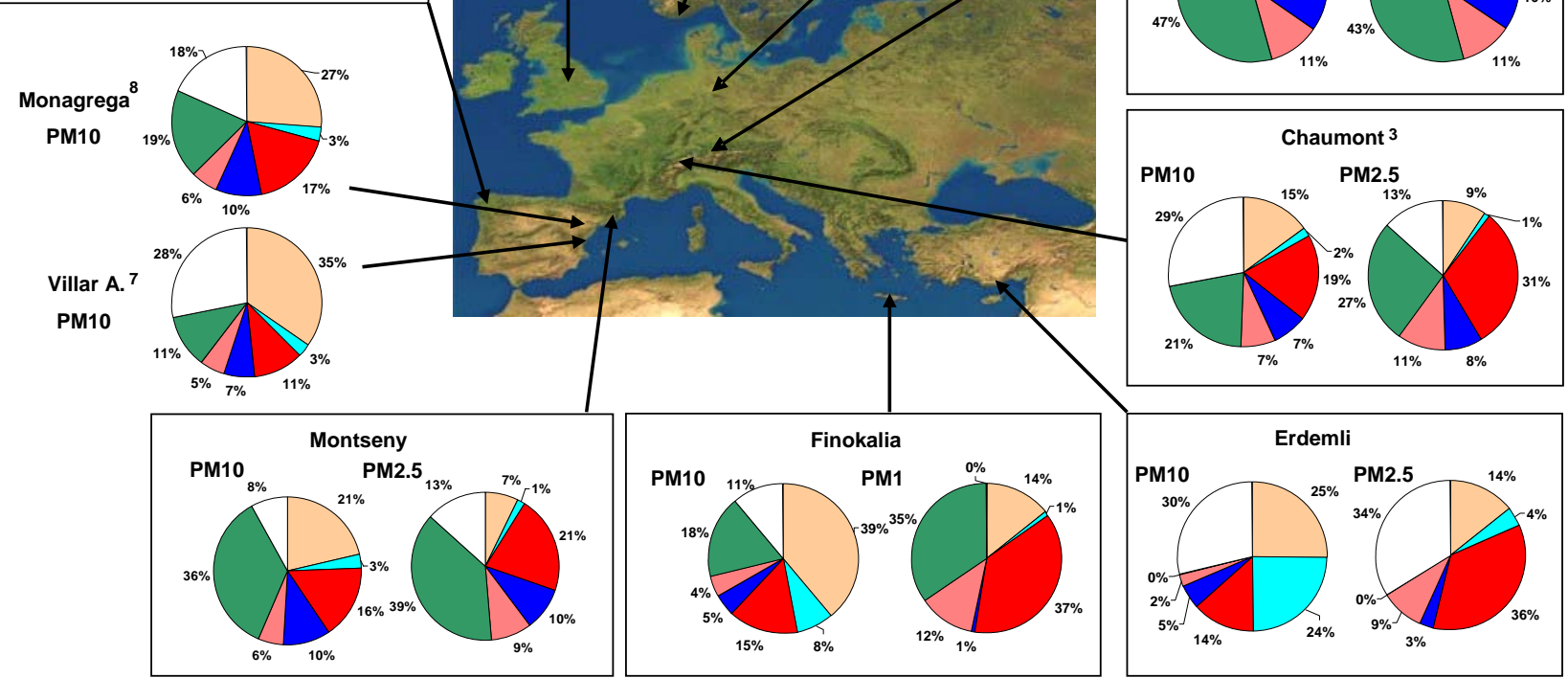
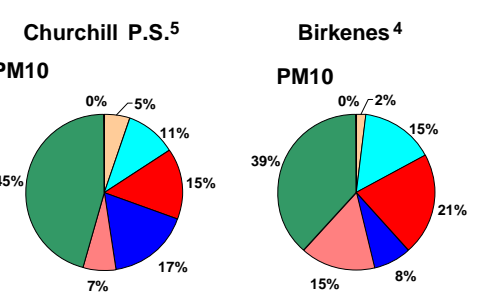

$15 \%$
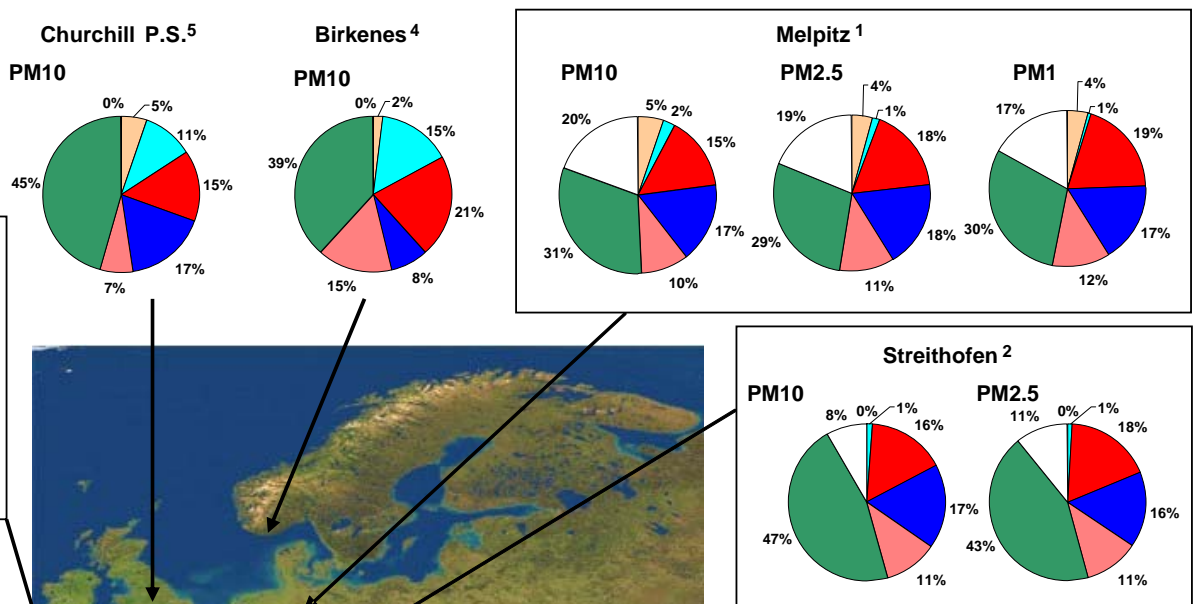

Fig. 6. Mean annual levels of $\mathrm{PM}_{10}$ and $\mathrm{PM}_{2.5}$ components measured at MSY, FKL and ERL and a selection of rural-regional background sites. ${ }^{1}$ Spindler et al. (2007); ${ }^{2}$ Puxbaum et al. (2004); ${ }^{3}$ Hueglin et al. (2005); ${ }^{4}$ Yttri (2007); ${ }^{5}$ Yin and Harrison (2008); ${ }^{6}$ Salvador et al. (2007); ${ }^{7}$ Viana et al. (2008); ${ }^{8}$ Rodriguez et al. (2004). OM + EC: organic matter + elemental carbon.

Carbonaceous aerosol concentrations are maximum in summer in the WMB (Fig. 5), coinciding with the lowest renovation of the atmosphere at a regional scale (Rodríguez et al., 2002; Pérez et al., 2008) and probably with high the higher formation of SOA from different natural and anthropogenic sources, as stated previously. Secondary peaks are usually observed in February-March and late autumn (Fig. 4), associated with the aforementioned winter anticyclonic pollution episodes. Carbonaceous compounds have a prevalent fine grain size, with $\mathrm{PM}_{2.5} / \mathrm{PM}_{10}$ ratios very close to 1 .

As previously reported, the OC/EC ratio reaches mean values close to 11 , however during most of the years this ratio decreased in winter and increased in summer, probably due to high SOA summer formation from biogenic, anthropogenic and biomass burning emissions, but also to the very low EC levels. At the EMB the OC/EC ratio is much lower ranging from 4 in $\mathrm{PM}_{1}$ to 5.4 in $\mathrm{PM}_{10}$. In addition, a statistically significant correlation occurs between fine OC and EC (slope equal to $4, r=0.73$ ), which does not change on a seasonal basis ( $r=0.65$ for winter and 0.86 for summer). Regarding the seasonal variation of both $\mathrm{OC}$ and $\mathrm{EC}$, maxima and minima occur during summer (July-August and June, respectively) and the max/min ratio of 1.6 (for OC) is lower than the respective for ionic composition.

Long-term (5-year) measurements of Black Carbon (BC) and OC in bulk aerosols performed in the EMB (Crete Island, Sciare et al., 2008) have shown that long-range transport of agricultural waste, and burning emissions from European countries surrounding the Black Sea, are important during two periods of the year, March-April and July-September. The contribution of biomass burning to the concentrations of BC and OC is shown to be rather small (20 and 14\%, respectively, on a yearly basis), although this contribution could be much higher on a monthly basis and is expected to have a high intra- and inter-annual variability. Removing the biomass burning influence, a prominent OC seasonal variation is revealed, with an increase by almost a factor of two during May and June, whereas BC is found to be quite stable throughout the year. 
Table 2. $\mathrm{PM}_{10}, \mathrm{PM}_{2.5}$ and $\mathrm{PM}_{1}$ levels for the main scenarios occurring at MSY, FKL and ERL. NAF, African dust outbreaks; EU, EUW, EUE, European air mass transport (total, Western and Eastern Europe); MED, Mediterranean air mass transport; WAE, winter anticyclonic episodes; ATL, Atlantic advective conditions; SE, Middle East and Arabian air mass transport; REG, regional re-circulations.

\begin{tabular}{|c|c|c|c|c|c|c|c|c|c|c|}
\hline & $\mu \mathrm{g} / \mathrm{m}^{3}$ & NAF & EU & EUW & EUE & MED & WAE & ATL & SE & REG \\
\hline \multirow{3}{*}{ MSY } & $\mathrm{PM}_{10}$ & 24 & 16 & & & 13 & 19 & 13 & & 20 \\
\hline & $\mathrm{PM}_{2.5}$ & 16 & 13 & & & 11 & 16 & 11 & & 15 \\
\hline & $\mathrm{PM}_{1}$ & 12 & 11 & & & 9 & 14 & 9 & & 12 \\
\hline FKL & $\mathrm{PM}_{10}$ & 54 & & 19 & 21 & 21 & & & & 19 \\
\hline \multirow{2}{*}{ ERL } & $\mathrm{PM}_{10}$ & 51 & & 34 & 40 & 30 & & & 56 & 33 \\
\hline & $\mathrm{PM}_{2.5}$ & 10 & & 10 & 9 & 8 & & & 8 & 11 \\
\hline
\end{tabular}

Table 3. Annual frequency, $\mathrm{PM}_{10}, \mathrm{PM}_{2.5}$ and $\mathrm{PM}_{1}$ levels and $\mathrm{PM}_{10}, \mathrm{PM}_{2.5}$ or $\mathrm{PM}_{1}$ composition (in \%) for the main scenarios occurring at MSY, FKL and ERL. NAF African dust outbreaks; WAE, winter anticyclonic episodes; REG, regional re-circulations, EU, European air mass transport (EUW, from Western Europe; EUE, from Eastern Europe) MED, Mediterranean air mass transport; ATL, Atlantic advective conditions; SE, South Eastern air mass transport.

\begin{tabular}{|c|c|c|c|c|c|c|c|c|c|c|c|c|c|c|c|c|c|c|}
\hline MSY & NAF & WAE & REG & EU & MED & ATL & FKL & NAF & EUW & EUE & MED & ERL & NAF & EUW & EUE & MED & SE & REG \\
\hline $\begin{array}{l}\text { Annual frequency } \\
\text { (\% days/year) }\end{array}$ & $12-24$ & $7-15$ & $14-20$ & $8-17$ & $2-7$ & $39-53$ & & 16 & 36 & 28 & 14 & & 8 & 5 & 8 & 7 & 10 & 62 \\
\hline$\mu \mathrm{gPM}_{10} / \mathrm{m}^{3}$ & 26 & 20 & 18 & 13 & 13 & 13 & $\begin{array}{l}\mu \mathrm{gPM}_{10} / \mathrm{m}^{3} \\
\text { (from VI) }\end{array}$ & 98 & 25 & 28 & 26 & $\mu \mathrm{gPM}_{10} / \mathrm{m}^{3}$ & 51 & 34 & 40 & 30 & 56 & 33 \\
\hline $\mathrm{OM}(\%)$ & 16 & 23 & 22 & 22 & 23 & 24 & $\mathrm{OM}(\%)$ & 8 & 21 & 15 & 20 & $\mathrm{OM}(\%)$ & & & & & & \\
\hline $\mathrm{EC}(\%)$ & 1 & 2 & 1 & 1 & 2 & 2 & $\mathrm{EC}(\%)$ & 0.4 & 2 & 1 & 2 & $\mathrm{EC}(\%)$ & & & & & & \\
\hline $\mathrm{SO}_{4}^{2-}(\%)$ & 14 & 14 & 20 & 14 & 17 & 15 & $\mathrm{SO}_{4}^{2-}(\%)$ & 5 & 23 & 21 & 17 & $\mathrm{SO}_{4}^{2-}(\%)$ & 8 & 10 & 8 & 10 & 5 & 15 \\
\hline $\mathrm{NO}_{3}^{-}(\%)$ & 6 & 22 & 5 & 10 & 9 & 12 & $\mathrm{NO}_{3}^{-}(\%)$ & 2 & 6 & 7 & 7 & $\mathrm{NO}_{3}^{-}(\%)$ & 3 & 4 & 4 & 3 & 2 & 6 \\
\hline $\mathrm{NH}_{4}^{+}(\%)$ & 4 & 8 & 6 & 6 & 5 & 6 & $\mathrm{NH}_{4}^{+}(\%)$ & 1 & 7 & 6 & 5 & $\mathrm{NH}_{4}^{+}(\%)$ & 2 & 2 & 1 & 2 & 1 & 3 \\
\hline Mineral (\%) & 40 & 16 & 22 & 14 & 23 & 22 & Mineral (\%) & 62 & 22 & 15 & 26 & Mineral (\%) & 50 & 24 & 28 & 30 & 21 & 31 \\
\hline Sea S. (\%) & 2 & 2 & 3 & 3 & 3 & 4 & Sea S. (\%) & 4 & 9 & 13 & 10 & Sea S. $(\%)$ & 28 & 26 & 30 & 30 & 47 & 28 \\
\hline $\operatorname{SIC}(\%)$ & 24 & 44 & 30 & 30 & 31 & 34 & $\operatorname{SIC}(\%)$ & 8 & 36 & 34 & 29 & $\operatorname{SIC}(\%)$ & 13 & 16 & 13 & 15 & 8 & 24 \\
\hline Unacc. (\%) & 17 & 14 & 21 & 31 & 18 & 17 & Unacc. $(\%)$ & 17.6 & 10 & 22 & 13 & Unacc. (\%) & 8 & 34 & 28 & 21 & 24 & 16 \\
\hline$\mu \mathrm{g} \mathrm{PM}_{2.5} / \mathrm{m}^{3}$ & 17 & 16 & 15 & 12 & 10 & 11 & $\begin{array}{l}\mu \mathrm{gPM}_{1} / \mathrm{m}^{3} \\
\text { (from VI) }\end{array}$ & 13 & 12 & 13 & 9 & $\mu \mathrm{gPM}_{2.5} / \mathrm{m}^{3}$ & 10 & 10 & 9 & 8 & 8 & 11 \\
\hline $\mathrm{OM}(\%)$ & 25 & 23 & 26 & 29 & 29 & 29 & $\mathrm{OM}(\%)$ & 17 & 31 & 23 & 35 & $\mathrm{OM}(\%)$ & & & & & & \\
\hline $\mathrm{EC}(\%)$ & 1 & 1 & 1 & 2 & 1 & 2 & $\mathrm{EC}(\%)$ & 2 & 2 & 2 & 3 & EC $(\%)$ & & & & & & \\
\hline $\mathrm{SO}_{4}^{2-}(\%)$ & 21 & 18 & 27 & 19 & 21 & 20 & $\mathrm{SO}_{4}^{2-}(\%)$ & 22 & 39 & 37 & 38 & $\mathrm{SO}_{4}^{2-}(\%)$ & 29 & 27 & 28 & 35 & 25 & 39 \\
\hline $\mathrm{NO}_{3}^{-}(\%)$ & 4 & 21 & 2 & 12 & 6 & 9 & $\mathrm{NO}_{3}^{-}(\%)$ & 1 & 1 & 1 & 1 & $\mathrm{NO}_{3}^{-}(\%)$ & 2 & 3 & 2 & 4 & 2 & 3 \\
\hline $\mathrm{NH}_{4}^{+}(\%)$ & 7 & 11 & 9 & 10 & 6 & 8 & $\mathrm{NH}_{4}^{+}(\%)$ & 7 & 13 & 12 & 13 & $\mathrm{NH}_{4}^{+}(\%)$ & 8 & 8 & 7 & 9 & 5 & 10 \\
\hline Mineral (\%) & 17 & 5 & 8 & 5 & 15 & 9 & Mineral (\%) & 28 & 4 & 4 & 11 & Mineral (\%) & 28 & 10 & 21 & 26 & 20 & 15 \\
\hline Sea S. $(\%)$ & 1 & 2 & 2 & 2 & 2 & 2 & Sea S. $(\%)$ & 1 & 1 & 1 & 1 & Sea S. $(\%)$ & 10 & 8 & 7 & 13 & 17 & 12 \\
\hline $\operatorname{SIC}(\%)$ & 32 & 44 & 37 & 41 & 33 & 37 & SIC $(\%)$ & 30 & 53 & 50 & 51 & SIC (\%) & 39 & 38 & 37 & 48 & 32 & 52 \\
\hline Unacc. (\%) & 24 & 20 & 25 & 22 & 19 & 22 & Unacc. $(\%)$ & 21 & 9 & 20 & 0 & Unacc. $(\%)$ & 23 & 45 & 35 & 14 & 31 & 21 \\
\hline$\mu \mathrm{gPM} / \mathrm{Pm}^{3}$ & 12 & 14 & 12 & 11 & 9 & 9 & & & & & & & & & & & & \\
\hline
\end{tabular}

\subsection{Influence of different meteorological scenarios and air mass origins on PM levels and chemical composition}

In both WMB and EMB the highest levels of $\mathrm{PM}_{10}(24$ and $51-54 \mu \mathrm{g} / \mathrm{m}^{3}$, respectively, Tables 2 and 3) are recorded under the transport of dust from Sahara and the Middle East/Arabian Peninsula. As expected, at both WMB and EMB, African dust outbreaks increase the proportion of mineral matter markedly in all size fractions $\left(40-62 \%\right.$ in $\mathrm{PM}_{10}$, and $17-28 \%$ in $\mathrm{PM}_{2.5}$ ). Carbonaceous aerosols under these episodes reach lowest contribution at all sites.

On the other hand, the lowest levels of $\mathrm{PM}_{10}$ for WMB and EMB (13 and $21-30 \mu \mathrm{g} / \mathrm{m}^{3}$ respectively, Table 2) are associated to the transport of marine air masses, from the Atlantic for the WMB and the Mediterranean for both basins. In the WMB the recirculation of air masses and the winter anticyclonic episodes increase $\mathrm{PM}_{10}$ levels markedly (20 and $19 \mu \mathrm{gPM}_{10} / \mathrm{m}^{3}$, respectively). In the case of the EMB, air masses from the Central and Northern European continent increase $\mathrm{PM}_{10}$ levels considerably $\left(20-40 \mu \mathrm{gPM}_{10} / \mathrm{m}^{3}\right)$, owing to the transport of anthropogenic pollutants emitted in Central Europe.

Therefore, at RB sites daily variability of PM levels is driven by the concatenation of different meteorological scenarios that may alter both levels and size of particulate matter.

As shown in Table 3, the transport of air masses from the Mediterranean and Western Europe causes similar proportions of OM in the WMB and EMB (21-23\% in $\mathrm{PM}_{10}$ and $29-31 \%$ in $\mathrm{PM}_{2.5}$ or $\mathrm{PM}_{1}$ ). The proportion of $\mathrm{OM}$ in the EMB decreases considerably when the transport of air 
masses is from Eastern Europe (15\% in $\mathrm{PM}_{10}$ and $23 \%$ in $\mathrm{PM}_{1}$ at FKL). The EC proportion does not present noticeable variations with the air mass origins.

Regional recirculations (REG) cause the highest proportion of sulphate in the WMB (MSY) and EMB (ERL). These proportions increase in the $\mathrm{PM}_{2.5}$ fraction with respect to the $\mathrm{PM}_{10}$ fraction (15-20\% in $\mathrm{PM}_{10}$, and $27-39 \%$ in $\mathrm{PM}_{2.5}$ ), due to prevailing low dispersive conditions and high photochemical oxidation. Sulphate also increases markedly at FKL under European transport (21-23\% $\mathrm{PM}_{10}$ and 37-39\% in $\mathrm{PM}_{1}$ ).

The nitrate proportion in the EMB is considerably lower than in the WMB. The nitrate and ammonium proportion at MSY is higher under WAE (21-22\% for nitrate and $8-11 \%$ for ammonium in both $\mathrm{PM}_{10}$ and $\mathrm{PM}_{2.5}$ ). The higher proportions of nitrate in the EMB occur under European transport and regional recirculations, representing only $4-6 \%$ of $\mathrm{PM}_{10}$.

\section{Conclusions}

PM levels and speciation for the period 2001 to 2008 at three typical regional background (RB) sites at the WMB and the EMB (Montseny/MSY - NE Spain, Finokalia/FKL - Southern Greece and Erdemli/ERL - Southern Turkey), are utilized, in conjunction with selected European sites, for the identification of major factors controlling levels and chemical composition that differentiate aerosols along the Mediterranean Basin.

The major findings of this study can be summarized as follows:

- A prominent W-E and N-S $\mathrm{PM}_{10}$ and $\mathrm{PM}_{2.5}$ increasing gradient along the Mediterranean Basin is found, while for $\mathrm{PM}_{1}$ similar levels are observed in both basins. These gradients are attributed to the proximity to dust sources and the higher frequency and intensity of African dust outbreaks in the EMB when compared with the WMB.

- In the WMB, PM levels follow a clear seasonal pattern with summer maximum due to lower precipitation, higher resuspension, photochemical transformations and frequent African episodes. A broader pattern is observed at the EMB with maxima in spring due to the higher frequency of dust episodes.

- Speciation data shows that PM in EMB is characterized by higher levels of crustal material and sulphate compared to WMB. RB nitrate and OC + EC levels are relatively constant across the Mediterranean.

- The main form of RB nitrate formed in the EMB is Na and $\mathrm{Ca}$ nitrate, with a dominant coarse grain size. Thus, the ratio of $\mathrm{PM}_{2.5} / \mathrm{PM}_{10}$ nitrate levels in the EMB is considerably lower $(0.1-0.2)$ than in central and northern EU and the WMB (0.7 to 0.8). Nitrate levels at
WMB present a strong seasonal variability with maxima during colder months and reduced levels in the warmer period. This can be related to the thermal instability of the ammonium nitrate in summer ambient conditions and to extremely intense nitrate episodes recorded every year from November to March. Contrarily, at the EMB nitrate presents higher values during summer and lower during winter, due to the combination of nitrate mostly with alkaline ion species.

- Sulphate levels at both parts of the basin increase progressively from April-May to reach maximum levels in mid summer, due to enhanced photochemistry, low air mass renovation at regional scale, the increment of the summer mixing layer depth favouring the regional mixing of polluted air masses, and the possible higher summer contribution of marine secondary sulphate from DMS oxidation. A small proportion of primary sulphate can not be discarded, but prior studies showed that the $\mathrm{S} / \mathrm{PM}$ ratio is very small in the free troposphere, when compared with the boundary layer during African dust episodes (Alastuey et al., 2005). In any case enhanced sulphate levels in EMB compared to WMB were measured. The high levels of sulphate in the EMB may deplete the available gas-phase $\mathrm{NH}_{3}$ so that little ammonium nitrate can form due to the low $\mathrm{NH}_{3}$ levels. Note that this is consistent with the aerosols in the EMB being acidic and those in the WMB being neutralized by $\mathrm{NH}_{4}^{+}$. This may be the reason for the coarse prevalence of nitrate in the EMB, where the interaction of $\mathrm{HNO}_{3}$ with sea salt and mineral matter may be favoured by the low $\mathrm{NH}_{3}$ available.

- The OC/EC ratio is close to 11 at MSY, and 4 at FLK, due to the lack of ventilation in WMB during springsummer and the enhanced formation of SOA from the oxidation of biogenic and anthropogenic VOCs, and also from VOCs emitted during forest fires. This has been shown to be a major cause of increased PM levels in many regions of the World, but it appears to be underestimated by current models (Volkamer et al., 2006). Thus the high OC/EC ratios measured at MSY can be explained by the high SOA formation from a combination of anthropogenic VOC precursors or biomass burning, or a combination of both. These two sources are enhanced in summer.

- Trace element levels (V and Ni) measured at both basins are relatively higher (by a factor of 3 to 9) than most sites in central Europe as a consequence of the relatively high emissions from fuel-oil combustion in the study area (power generation, industrial and shipping emissions).

- Compared to central European sites, PM at Mediterranean RB is characterized by relatively high levels of crustal material and sulphate (EMB), and lower levels 
of OM+EC and nitrate. Special Mediterranean features may account for these differences: a) Crustal material: The lower atmospheric rain scavenging potential, the high frequency of African dust outbreaks and the higher emissions (anthropogenic and natural). b) Sulphate: The higher $\mathrm{SO}_{2}$ emissions, lower ventilation of the atmospheric basin and higher photochemistry. c) $\mathrm{OM}+\mathrm{EC}$ : Lower use of biomass combustion in winter. d) Nitrate: Higher ambient temperature favouring the gas phase prevalence of nitrate.

Overall, it is shown that the peculiar atmospheric dynamics and emission sources of the Mediterranean Basin decisively influence the levels and chemical composition of RB aerosols. Particularly contrasting meteorological patterns in the Western and Eastern parts of the basin occur, as mentioned previously, give rise to significantly different characteristics of PM. Thus, the Mediterranean is a very distinctive region when compared with other regions in Europe, and should be considered when modelling climate effects of aerosols and when evaluating air quality at European scales.

Finally, this study clearly demonstrates why the Mediterranean is included among the most vulnerable regions globally by means of climate destabilization, as well as the significant and complicated role that aerosols play as a forcing driver. The provided comparisons also highlight air quality degradation in the area and identify the major sources and important processes responsible. This is very useful for implementing strategies that will have an impact on health concerns but also policy issues such as identification and discrimination between anthropogenic and natural contributions.

Acknowledgements. This study was supported by the Ministry of Science and Innovation (CGL2005-03428-C04-03/CLI, CGL2007-62505/CLI, GRACCIE-CSD2007-00067), the European Union (6th framework CIRCE IP, 036961, EUSAAR RII3-CT2006-026140). The authors would also like to acknowledge NASA/Goddard Space Flight Center, SeaWIFS-NASA Project, University of Athens, Navy Research Laboratory-USA and the Barcelona Super-Computing Centre for their contribution with TOMS maps, satellite images, SKIRON dust maps, NAAPs aerosol maps, and DREAM dust maps, respectively. The authors gratefully acknowledge the NOAA Air Resources Laboratory (ARL) for the provision of the HYSPLIT transport and dispersion model and/or READY website (http://www.arl.noaa.gov/ready.html) used in this publication. We would like to express our gratitude to Jesús Parga for his technical support and to Airbase-EEA for allowing free access to ambient PM levels recorded at a large number of sites in Europe, some of these data have been used in this study. Finally, we appreciate very much the comments made by Wenche Aas and 2 anonymous referees, as well as a pre-submission review done by José Luis Jimenez. All these reviews improved substantially the quality of our paper.

Edited by: V.-M. Kerminen

\section{References}

Alastuey, A., Querol, X., Castillo, S., Escudero, M., Avila, A., Cuevas, E., Torres, C., Romero, P. M., Exposito, F., Garcia, O., Diaz, J. P., Dingenen, R. V., and Putaud, J. P.: Characterisation of TSP and PM2.5 at Izaña and Sta. Cruz de Tenerife (Canary Islands, Spain) during a Saharan dust episode (July 2002), Atmos. Environ., 39 (26), 4715-4728, 2005.

Aiken, A. C., DeCarlo, P. F., Kroll, J. H., Worsnop, D. R., Huffman, J. A., Docherty, K., Ulbrich, I. M., Mohr, C., Kimmel, J.,R., Sueper, D., Zhang, Q., Sun, Y., Trimborn, A., Northway, M., Ziemann, P. J., Canagaratna, M. R., Onasch, T. B., Alfarra, R., Prévôt, A. S. H., Dommen, J., Duplissy, J., Metzger, A., Baltensperger, U., and Jimenez, J. L.: O/C and OM/OC Ratios of Primary, Secondary, and Ambient Organic Aerosols with HighResolution Time-of-Flight Aerosol Mass Spectrometry, Environ. Sci. Technol., 42, 4478-4485, 2005.

Balis, D. S., Amiridis, V., Zerefos, C., Gerasopoulos, E., Andreae, M. O., Zanis, P., Kazantzidis, A., Kazadzis, S., and Papayannis, A.: Raman lidar and sunphotometric measurements of aerosol optical properties during a biomass burning episode over Thessaloniki, Greece, Atmos. Environ., 37, 4529-4538, 2003.

Bardouki, H., Liakakou, H., Economou, C., Sciare, J., Smolik, J., Zdimal, V., Eleftheriadis, K., Lazaridis, M., Dye, C., and Mihalopoulos, N.: Chemical composition of size-resolved atmospheric aerosols in the eastern Mediterranean during summer and winter, Atmos. Environ. 37, 195-208, 2003.

Birch, M. and Cary, R.: Elemental carbon-based method for monitoring occupational exposures to diesel particulate diesel exhaust, Aerosol Sci. Technol., 25, 221-241, 1996.

Borbely-Kiss, I., Koltay, E., Szabo, G. Y., Bozo, L., and Tar, K.: Composition and sources of urban and rural atmospheric aerosol in Eastern Hungary, J. Aerosol Sci., 30, 369-391, 1999.

Dongarrà, G., Manno, E., Varrica, D., and Vultaggio, M.: Mass levels, crustal component and trace elements in $\mathrm{PM}_{10}$ in Palermo, Italy, Short communication, Atmos. Environ., 41, 7977-7986, 2007.

Draxler, R. R. and Rolph, G. D.: HYSPLIT (HYbrid Single-Particle Lagrangian Integrated Trajectory) Model access via NOAA ARL READY Website (http://www.arl.noaa.gov/ready/hysplit4.html), NOAA Air Resources Laboratory, Silver Spring, MD, 2003.

Escudero, M., Castillo, S., Querol, X., Avila, A., Alarcón, M., Viana, M. M., Alastuey, A., Cuevas, E., and Rodríguez, S.: Wet and dry African dust episodes over Eastern Spain, J. Geophys. Res., 110, D18S08, doi:10.1029/2004JD004731, 2005.

Gangoiti, G., Millán, M. M., Salvador, R., and Mantilla, E.: Long range transport and re-circulation of pollutants in the Western Mediterranean during the RECAPMA Project, Atmos. Environ., 35, 6267-6276, 2001.

Gerasopoulos, E., Kouvarakis, G., Vrekoussis, M., Kanakidou, M., and Mihalopoulos, N.: Ozone variability in the marine boundary layer of the Eastern Mediterranean based on 7-year observations. Journal of Geophysical Research 110, D15309, doi:10.1029/2005JD005991, 2005..

Gerasopoulos, E., Kouvarakis, G., Babasakalis, P., Vrekoussis, M., Putaud, J.-P., and Mihalopoulos, N.: Origin and variability of particulate matter (PM10) mass concentrations over the Eastern Mediterranean, Atmos. Environ., 40(25), 4679-4690, 2006. 
Gerasopoulos, E., Koulouri, E., Kalivitis, N., Kouvarakis, G., Saarikoski, S., Mkel, T., Hillamo, R., and Mihalopoulos, N.: Size-segregated mass distributions of aerosols over Eastern Mediterranean: seasonal variability and comparison with AERONET columnar size-distributions, Atmos. Chem. Phys., 7, 2551-2561, 2007,

http://www.atmos-chem-phys.net/7/2551/2007/.

Glavas, S. D., Nikolakis, P., Ambatzoglou, D., and Mihalopoulos, N.: Factors affecting the seasonal variation of mass and ionic composition of PM2.5 at a central Mediterranean coastal site, Atmos. Environ., 42, 5365-5373, 2008.

Hallquist, M., Wenger, J. C., Baltensperger, U., Rudich, Y., Simpson, D., Claeys, M., Dommen, J., Donahue, N. M., George, C., Goldstein, A. H., Hamilton, J. F., Herrmann, H., Hoffmann, T., Iinuma, Y., Jang, M., Jenkin, M., Jimenez, J. L., Kiendler-Scharr, A., Maenhaut, W., McFiggans, G., Mentel, Th. F., Monod, A., Prévôt, A. S. H., Seinfeld, J. H., Surratt, J. D., Szmigielski, R., and Wildt, J.: The formation, properties and impact of secondary organic aerosol: current and emerging issues, Atmos. Chem. Phys. Discuss., 9, 3555-3762, 2009,

http://www.atmos-chem-phys-discuss.net/9/3555/2009/.

Harrison, R. M. and Pio, C.: Size differentiated composition of inorganic aerosol of both marine and continental polluted origin, Atmos. Environ., 17, 1733-1738, 1983.

Hueglin, C., Gehrig, R., Baltensperger, U., Gysel, M., Monn, C., and Vonmont, H.: Chemical characterisation of PM2.5, PM10 and coarse particles at urban, near-city and rural sites in Switzerland, Atmos. Environ., 39, 637-651, 2005.

IPCC: Climate Change 2007: The Physical Science Basis, Contribution of Working Group I to the Fourth Assessment Report of the IPCC, ISBN 9780521 88009-1 Hardback; 9780521 70596-7 Paperback, 2007.

Jorba, O., Pérez, C., Rocadenbosch, F., and Baldasano, J. M.: Cluster Analysis of 4-Day Back Trajectories Arriving in the Barcelona Area (Spain) from 1997 to 2002, J. Appl. Meteorol, 43(6), 887-901, 2004.

Kallos, G., Kotroni, V., and Lagouvardos, K.: Proceedings of the Symposium on Regional Weather Prediction on Parallel computer Environments, University of Athens, Greece, 109-122, 1997.

Kalnay, E., Kanamitsu, M., Kistler, R., Collins, W., Deaven, D., Gandin, L., Iredell, M., Saha, S., White, G., Woollen, J., Zhu, Y., Chelliah, M., Ebisuzaki, W., Higgins, W., Janowiak, J., Mo, K. C., Ropelewski, C., Wang, J., Leetmaa, A., Reynolds, R., Jenne, R., and Joseph, D., 1996. The NCEP/NCAR 40-Year Reanalysis Project, B. Am. Meteorol. Soc., 77, 437-471, 1996.

Koçak, M., Kubilay, N., and Mihalopoulos, N.: Ionic composition of lower tropospheric aerosols at a Northeastern Mediterranean site: implications regarding sources and long-range transport, Atmos. Environ., 38, 2067-2077, 2004.

Koçak, M., Mihalopoulos, N., and Kubilay, N.: Contributions of natural sources to high PM10 and PM2.5 events in the eastern Mediterranean, Atmos. Environ., 41(18), 3806-3818, 2007a.

Koçak, M., Mihalopoulos, N., and Kubilay, N.: Chemical composition of the fine and coarse fraction of aerosols in the northeastern Mediterranean, Atmos. Environ., 41(34), 7351-7368, $2007 \mathrm{~b}$.

Koulouri, E., Saarikoski, S., Theodosi, C., Markaki, Z., Gerasopoulos, E., Kouvarakis, G., Mäkelä, T., Hillamo, R., and Mihalopoulos, N.: Chemical composition and sources of fine and coarse aerosol particles in the Eastern Mediterranean, Atmos. Environ., 42(26), 6542-6550, 2008.

Kubilay, N., Nickovic, S., Moulin, C., and Dulac, F.: An illustration of the transport and deposition of mineral dust onto the eastern Mediterranean, Atmos. Environ., 34, 1293-1303, 2000.

Lall, R. and Thrurston, G. D.: Identifying and quantifying transported vs. local sources of New York City PM2.5 fine particulate matter air pollution, Atmos. Environ., 40, S333-S346, 2006.

Larssen, S., Sluyter, R., and Helmis, C.: Criteria for EUROAIRNET, the EEA air quality monitoring and information network, available at: http://reports.eea.eu.int/TEC12/en, 1999.

Mamane, Y. and Gottlieb, J.: Nitrate formation on sea salt and mineral particles - a single particle approach, Atmos. Environ. AGen., 26, 1763-1769, 1992.

Marenco, P., Bonasoni, F., Calzolari, M., Ceriani, M., Chiari, J., and Cristofanelli, P.: Characterization of atmospheric aerosols at Monte Cimone, Italy, during summer 2004: source apportionment and transport mechanisms, J. Geophys. Res., 111, D24202, doi:10.1029/2006JD007145, 2006.

McClain, C. R., Cleave, M. L., Feldman, G. C., Gregg, W. W., Hooker, S. B., and Kuring, N.: Science Quality SeaWiFS Data for Global Biosphere Research, Sea Technol., 39, 10-15, 1998.

Metzger, S., Mihalopoulos, N., and Lelieveld, J.: Importance of mineral cations and organics in gas-aerosol partitioning of reactive nitrogen compounds: case study based on MINOS results, Atmos. Chem. Phys., 6, 2549-2567, 2006,

http://www.atmos-chem-phys.net/6/2549/2006/.

Mihalopoulos, N., Stephanou, E., Kanakidou, M., Pilitsidis, S., and Bousquet, P., 1997. Troposheric aerosol ionic composition above the Eastern Mediterranean area, Tellus B, 49, 314-326, 1997.

Mihalopoulos, N., Kerminen, V. M., Kanakidou, M., Berresheim, H., and Sciare, J.: Formation of particulate sulfur species (sulphate and methanesulfonate) during summer over the Eastern Mediterranean: A modelling approach, Atmos. Environ., 41(32), 6860-6871, 2007.

Millán, M., Salvador, R., Mantilla, E., and Kallos, G.: Photooxidant dynamics in the Mediterranean basin in summer: results from European research projects, J.Geophys. Res., 102, 88118823, 1997.

Mitsakou, C., Kallos, G., Papantoniou, N., Spyrou, C., Solomos, S., Astitha, M., and Housiadas, C.: Saharan dust levels in Greece and received inhalation doses, Atmos. Chem. Phys., 8, 71817192, 2008, http://www.atmos-chem-phys.net/8/7181/2008/.

Moulin, C., Lambert, E., Dayan, U., Masson, V., Ramonet, M., Bousquet, P., Legrand, M., Balkanski, Y. J., Guelle, W., Marticorena, B., Bergametti, G. and Dulac, F.: Satellite climatology of African dust transport in the Mediterranean atmosphere, J. Geophys. Res., 103, 13 137-13 144, 1998.

Pakkanen, T. A., Hillamo, R. E., Aurela, M., Andersen, H. V., Grundahl, L., Ferm, M., Persson, K., Karlsson, V., Reissell, A., Royset, O., Floisand, I., Oyola, P., and Ganko, T.: Nordic intercomparison for measurement of major atmospheric nitrogen species, J. Aerosol Sci., 30, 247-263, 1999.

Peñuelas, J., Llusià, J., and Gimeno, B. S.: Effects of ozone concentrations on biogenic volatile organic compounds emission in the Mediterranean region, Environ. Pollut., 105, 17-23, 1999.

Pérez, C., Sicard, M., Jorba, O., Comeron, A., Baldasano, J. M.: Summertime re-recirculations of air pollutants over the north- 
eastern Iberian coast observed from systematic EARLINET lidar measurements in Barcelona, Atmos. Environ., 38, 3983-4000, 2004.

Pérez, C., Nickovic, S., Pejanovic, G., Baldasano, J. M., Özsoy, E.: Interactive dust-radiation modelling: a step to improve weather forecasts, J. Geophys. Res., 111, D16206, doi:10.1029/2005JD006717, 2006.

Pérez, N., Castillo, S., Pey, J., Alastuey, A., Viana, M., and Querol, X., 2008. Interpretation of the variability of regional background aerosols in the Western Mediterranean, Sci. Total Environ., 407, 527-540.

Pio, C. A., Legrand, M., Oliveira, T., Afonso, J., Santos, C., Caseiro, A., Fialho, P., Barata, F., Puxbaum, H., Sanchez-Ochoa, A., Kasper-Giebl, A., Gelencsér A., Preunkert, S., and Schock, M.: Climatology of aerosol composition (organic versus inorganic) at non-urban areas on a West-East transect across Europe, J. Geophys. Res., 112, D23S02, doi:10.1029/2006JD008038, 2007.

Pope, C. A. and Dockery, D. W.: Health effects of fine particulate air pollution: lines that connect, J. Air. Waste Manage., 56(6), 709-42, 2006.

Putaud, J.-P., Van Dingenen, R., Dell'Acqua, A., Raes, F., Matta, E., Decesari, S., Facchini, M. C., and Fuzzi, S.: Size-segregated aerosol mass closure and chemical composition in Monte Cimone (I) during MINATROC, Atmos. Chem. Phys., 4, 889-902, 2004,

http://www.atmos-chem-phys.net/4/889/2004/.

Puxbaum, H., Gomišcek, B., Kalina, M., Bauer, H., Salam, A., Stopper, S., Preining, O., and Hauck, H.: A dual site study of PM2.5 and PM10 aerosol chemistry in the larger region of Vienna, Austria. Atmos. Environ., 38, 3949-3958, 2004.

Querol, X., Alastuey, A., Puicercus, J. A., Mantilla, E., Miro, J. V., Lopez-Soler, A., Plana, F., and Artínano, B.:Seasonal evolution of suspended particles around a large coal-fired power station: particulate levels and sources, Atmos. Environ., 32, 1963-1978, 1998.

Querol, X., Alastuey, A., Rodríguez, S., Plana, F., Mantilla, E., and Ruiz, C.R.: Monitoring of PM10 and PM2.5 around primary particulate anthropogenic emission sources, Atmos. Environ., 35, 845-858, 2001.

Querol, X., Alastuey, A., Viana, M. M., Rodríguez, S., Artíñano, B., Salvador, P., Santos, S. G. D., Patier, R. F., Ruiz, C. R., Rosa, J. D. L., Campa, A. S. D. L., Menedez, M., and Gil, J. I.: Speciation and origin of PM10 and PM2.5 in Spain, J. Aerosol Sci., 35, 1151-1172, 2004.

Querol, X, Alastuey, A., Moreno, T., Viana, M. M., Castillo, S., Pey, J., Rodríguez, S., Artiñano, B., Salvador, P., Sánchez, M., Garcia, Dos Santos, S., Herce Garraleta, M. D., Fernandez-Patier, R., Moreno-Grau, S., Minguillón, M. C., Monfort, E., Sanz, M. J., Palomo-Marín, R., Pinilla-Gil E., Cuevas, E., De La Rosa, J., and Sanchez De La Campa, A.: Spatial and temporal variations in airborne particulate matter (PM10 and PM2.5) across Spain 1999-2005, Atmos. Environ., 42, 3964-3979, 2008.

Querol, X., Pey, J., Pandolfi, M., Alastuey, A., Cusack, M., Pérez, N., Moreno, T., Viana, M., Mihalopoulos, N., Kallos, G., and Kleanthous, S.: African dust contributions to mean ambient $\mathrm{PM}_{10}$ mass-levels across the Mediterranean Basin, Atmos. Environ. doi:10.1016/j.atmosenv.2009.06.013, in press, 2009.
Reid, J. S., Koppmann, R., Eck, T. F., and Eleuterio, D. P.: A review of biomass burning emissions part II: intensive physical properties of biomass burning particles, Atmos. Chem. Phys., 5, 799825,2005 ,

http://www.atmos-chem-phys.net/5/799/2005/.

Rodríguez, S., Querol, X., Alastuey, A., and Mantilla, E.: Origin of high PM10 and TSP concentrations in summer in Eastern Spain, Atmos. Environ., 36, 3101-3112, 2002.

Rodríguez, S., Querol, X., Alastuey, A., Viana, M. M., and Mantilla, E.: Events affecting levels and seasonal evolution of airborne particulate matter concentrations in the Western Mediterranean, Environ. Sci. Technol., 37, 216-222, 2003.

Rodriguez, S., Querol, X., Alastuey, A., Viana, M. M., Alarcón, M., Mantilla, E., and Ruiz, C. R.: Comparative PM10-PM2.5 source contribution study at rural, urban and industrial sites during PM episodes in Eastern Spain, Science of the Total Environment, 328, 95-113, 2004.

Rodwell, M. J. and Hoskins, B. J.: Subtropical anticyclones and summer monsoons, J. Climate, 14, 3192-3211, 2001.

Saliba, N. A., Kouyoumdjian, H., and Roumie, M.: Effect of local and long range transport emissions on the elemental composition of $\mathrm{PM}_{10}-2.5$ and $\mathrm{PM}_{2.5}$ in Beirut, Atmos. Environ., 41(31), 6497-6509, 2007.

Salvador, P., Artíñano, B., Querol, X., Alastuey, A., and Costoya, M.: Characterisation of local and external contributions of atmospheric particulate matter at a background coastal site, Atmos. Environ., 41, 1-17, 2007.

Sciare, J., Oikonomou, K., Favez, O., Liakakou, E., Markaki, Z., Cachier, H., and Mihalopoulos, N.: Long-term measurements of carbonaceous aerosols in the Eastern Mediterranean: evidence of long-range transport of biomass burning, Atmos. Chem. Phys., 8, 5551-5563, 2008, http://www.atmos-chem-phys.net/8/5551/2008/.

Soriano, C., Baldasano, J. M, Buttler, W. T., and Moore, K.: Circulatory Patterns of Air Pollutants within the Barcelona Air Basin in a Summertime situation: Lidar and Numerical Approaches, Bound.-Lay. Meteorol., 98(1), 33-55, 2001.

Spindler, G., Brüggemann, E., Gnauk, T., Grüner, A., Müller, K., Tuch, Th. M., Wallasch, M. B., Wehner, A., and Herrmann, H.: Size-segregated physical and chemical long-time characterization of particles depending from air mass origin at German lowlands (Saxony, Melpitz site), EMEP Particulate Matter Assessment Report, Part B, Annex A, NILU, report EMEP/CCC-Report 8/2007, ref. O-7726, 178-221, August 2007.

Szabo, G. Y. and Borbely-Kiss, I.: PIXKLM computer package for PIXE analyses, Nucl. Instrum. Meth. B, 75, 123-126, 1993.

Turpin, B. J. and Lim, H. J.: Species contributions to PM2.5 mass concentrations: Revisiting common assumptions for estimating organic mass, Aerosol Sci. Technol., 35(1), 602-610, 2001.

Vestreng, V., Myhre, G., Fagerli, H., Reis, S., and Tarras'n, L.: Twenty-five years of continuous sulphur dioxide emission reduction in Europe, Atmos. Chem. Phys., 7, 3663-3681, 2007

Viana, M., Querol, X., Alastuey, A., Cuevas, E., Rodríguez, S.: Influence of African dust on the levels of atmospheric particulates in the Canary Islands air quality network, Atmos. Environ., 36, 5861-5875, 2002.

Viana, M., Querol, X., Ballester, F., Llop, S., Esplugues, A., Fernández Patier, R., García Dos Santos, S., and Herce, M. D.: Characterising exposure to PM aerosols for an epidemiological 
study, Atmos. Environ., 42, 1552-1568, 2008.

Visser, H., Buringh, E., and van Breugel, P. B.: Composition and origin of airborne particulate matter in the Netherlands. National Institute for Public Helath and the Environment, RIVM, The Netherlands, Report 650010029, 104 pp., 2001.

Volkamer, R., Jimenez, J. L., San Martini, F., et al.: Secondary organic aerosol formation from anthropogenic air pollution: Rapid and higher than expected, Geophys. Res. Lett., 33, L17811, doi:10.1029/2006GL026899, 2006.
Yin, J. and Harrison, R. M.: Pragmatic mass closure study for PM1.0, PM2.5 and PM10 at roadside, urban background and rural sites, Atmos. Environ. 42, 980-988, 2008.

Yttri, K. E.: Concentrations of particulate matter (PM10, PM2.5) in Norway. Annual and seasonal trends and spatial variability. EMEP Particulate Matter Assessment Report, Part B, Annex A, NILU, report EMEP/CCC-Report 8/2007, ref. O-7726, 292-307, August 2007. 